\title{
18 \\ Chemistry of the Lower Mantle
}

\author{
Daniel J. Frost and Robert Myhill
}

\begin{abstract}
Various lines of evidence have been used to argue that the lower mantle is chemically distinct in major elements from the upper mantle. One of the few approaches that may clarify this would be to compare observed seismic velocities with estimates computed from mineral physical models. This requires a method for determining the chemistry and modes of mantle minerals for a given bulk composition as a function of pressure and temperature. Aside from phase changes near the core-mantle boundary, the main change taking place throughout the bulk of an isochemical mantle will be the exchange of Fe between the principal minerals ferropericlase and bridgmanite. Here we review experimental data for this exchange and present simple models to describe this behavior. All experimental data to date seem to indicate that bridgmanite will contain subequal proportions of both $\mathrm{Fe}^{2+}$ and $\mathrm{Fe}^{3+}$ throughout much of the lower mantle. If the entire mantle is isochemical, the low $\mathrm{Fe}^{3+}$ contents of the upper mantle imply that metallic Fe should exist in the lower mantle. An alternative hypothesis is that the lower mantle is oxygen enriched but becomes reduced by the oxidation of species such as carbon during upwelling.
\end{abstract}

\subsection{INTRODUCTION}

Earth's lower mantle, extending from 660 to $2891 \mathrm{~km}$ depth, contains $\sim 70 \%$ of the mass of the mantle and is $\sim 50 \%$ of the mass of the entire planet [Dziewonski and Anderson, 1981]. Due to its size, the lower mantle has a large potential to bias the composition of the bulk silicate Earth (BSE), which in major element terms is generally assumed to be the same as the upper mantle [Allegre et al., 1995; McDonough and Sun, 1995; O'Neill and Palme, 1998]. Any chemical differences between the upper and lower mantle would have major implications for our understanding of the scale of mantle convection, the origin of the terrestrial heat flux, and aspects such as the volatile content of the interior. Furthermore, many

Bayerisches Geoinsitut, University Bayreuth, Bayreuth, Germany constraints on the processes involved in the accretion and differentiation of Earth would be lost if element concentrations in the upper mantle could not be reliably assumed to reflect the mantle as a whole.

Ultimately the best prospect for determining whether the lower mantle has the same major element composition as the upper mantle is to compare seismic reference models for shear and longitudinal wave velocities in the lower mantle with mineral physical estimates for what these velocities should be if the mantle is isochemical [Birch, 1952; Anderson, 1968; Jackson, 1983; Stixrude and Jeanloz, 2007; Murakami et al., 2012; Cottaar et al., 2014; Wang et al., 2015]. Such comparisons require not only high-pressure and high-temperature equation-of-state data for mantle minerals but also knowledge of the proportion and composition of minerals in the lower mantle for a given bulk composition. Significant uncertainties exist for both types of data. It must also be recognized that any fit to observed

Deep Earth: Physics and Chemistry of the Lower Mantle and Core, Geophysical Monograph 217, First Edition. Edited by Hidenori Terasaki and Rebecca A. Fischer.

(C) 2016 American Geophysical Union. Published 2016 by John Wiley \& Sons, Inc. 
lower mantle velocities in terms of temperature and composition is unlikely to be unique [Bina and Helffrich, 2014]. This approach may nevertheless be effective at excluding some hypotheses concerning the composition and thermal structure of the lower mantle.

Here arguments for plausible bulk chemical compositions of the lower mantle are briefly reviewed, followed by a discussion of how the mineralogy of the lower mantle and in particular the chemical compositions of minerals may change with depth. Determining a mineralogical model of this type is a key step toward the goal of calculating precise densities and seismic velocities for plausible lower mantle compositions.

\subsection{EVIDENCE FOR CHEMICALLY DISTINCT LOWER MANTLE}

The lack of earthquakes at depths greater than $700 \mathrm{~km}$ was one of the earliest lines of evidence used to argue that the subducted lithosphere did not penetrate into the lower mantle [Oliver and Isacks, 1967]. This combined with observations of a global seismic discontinuity at similar depths and early interpretations of the density through the lower mantle formed the basis for the hypothesis that the lower mantle could be chemically isolated and not involved in the convective processes responsible for plate tectonics [Anderson, 1968; Richter and Johnson, 1974; Richter and McKenzie, 1978; Anderson, 1979]. The principal evidence against this has come from seismic tomography that shows that some slabs stagnate at $660 \mathrm{~km}$ [see Fukao et al., 2001] while others penetrate directly into the lower mantle [Creager and Jordan, 1984; van der Hilst et al., 1997; Grand, 2002; Fukao and Masayuki, 2013]. This has provided the most compelling evidence for wholemantle convection but it does not necessarily mean that the lower mantle has the same composition as the upper mantle, as it remains difficult to quantify the total mass exchange between the upper and lower mantle over the last 4.5 Gyr.

Geodynamic simulations have also been used to argue for an isolated lower mantle. At the top of the lower mantle $(660 \mathrm{~km})$ the breakdown reaction of the mineral ringwoodite into an assemblage of ferropericlase and perovskite-structured $(\mathrm{Mg}, \mathrm{Fe}) \mathrm{SiO}_{3}$, now called bridgmanite [Tschauner et al., 2014], appears to have a negative Clausius-Clapeyron slope [Liu, 1974, 1975, 1976; Ito and Takahashi, 1989; Ito et al., 1990]. Models indicate that a large negative slope of between -4 and $-8 \mathrm{MPa} / \mathrm{K}$ would cause a local inversion in buoyancy that could induce two-layered mantle convection [Christensen and Yuen, 1985]. While experimental estimates for the slope of the transformation are closer to $-3 \mathrm{MPa} / \mathrm{K}[$ Ito and Takahashi, 1989; Ito et al., 1990] and may be as low as
-2 to $-0.4 \mathrm{MPa} / \mathrm{K}$ [Katsura et al., 2003], it should be noted that recent experimental studies also predict transition pressures for the transformation that are too low to explain the discontinuity at all. The absolute pressure and Clapeyron slope determined for the transition may well be unreliable due to a lack of a rigorously calibrated high-temperature pressure marker. Models suggest that an increase in viscosity around the upper-lower mantle boundary would also inhibit whole-mantle convection. An $~ 30$ times increase in viscosity would cause slabs to buckle within the mantle transition zone [Gaherty and Hager, 1994], in agreement with tomographic images [e.g., Li and van der Hilst, 2010] and analysis of focal mechanisms and earthquake locations [Myhill, 2013]. Ringwood [1982, 1991], recognizing that complete twolayered mantle convection may be unlikely, proposed that subducted material may tend to accumulate at $660 \mathrm{~km}$ but after sufficient thermal equilibration material would avalanche through into the lower mantle. Three-dimensional (3D) geodynamic simulations appear to support this scenario [Tackley et al., 1993; Solheim and Peltier, 1994], and it has been proposed that such avalanches could trigger superplume events, which may have been responsible for the episodic growth of the continental crust [Condie, 1998].

Chemical differences between the upper and lower mantle have long been invoked by geochemists to explain the isotopic and trace element heterogeneity displayed by ocean island basalts (OIBs), which are often considered to be the product of plumes rising from the lower mantle. The OIB source appears nominally "primitive" and unaffected by the partial-melting events linked to the formation of the continental crust, which has depleted the source of midocean ridge basalt (MORB) in incompatible elements [see Hofmann, 2014]. This depletion is consistent with a small-degree melting event that would not have significantly influenced the concentrations of major elements but appears, for example, to have left the MORB source too depleted in heat-producing elements (U, Th, K) to account for the expected radiogenic component of Earth's surface heat flow. This and similar arguments involving rare gases have led many studies to conclude that the lower mantle holds an undepleted and undegassed reservoir [Jochum et al., 1983; Albarède and van der Hilst, 2002; Arevalo et al., 2009]. Early mass balance estimates indicated that the depleted MORB source may be $\sim 30 \%$ of the mass of the mantle [Jacobsen and Wasserburg, 1979], which leaves the primitive reservoir with the same mass as the lower mantle. More recent estimates for the mass of the MORB source reservoir are much larger, however, [Jackson and Jellinek, 2013; Hofmann, 2014] and imply that the primitive reservoir may be only a fraction of the lower mantle. Isotopic evidence for the presence of ancient recycled crust in the 
OIB source [Lassiter and Hauri, 1998; Sobolev et al., 2000] is similarly at odds with the perception of a mainly isolated primitive lower mantle. Convection in the lower mantle may, however, favor reentrainment of recycled material into plumes at the base of the mantle, leaving a sizable proportion of the lower mantle chemically isolated [Solomatov and Reese, 2008; Campbell and O'Neill, 2012].

\subsection{POTENTIAL ORIGINS OF CHEMICALLY DISTINCT LOWER MANTLE}

Although it is unlikely that Earth formed from any single class of meteorite, major element ratios estimated for the BSE support Earth's similarity with carbonaceous chondrites [O'Neill and Palme, 1998]. Table 18.1 shows a range of silicate Earth compositions determined from bulk analyses of the major chondritic meteorite groups [Wasson and Kallemeyn, 1988]. The compositions were calculated by assuming a mantle $\mathrm{FeO}$ concentration of $8 \mathrm{wt} \%$ and separating the remaining $\mathrm{Fe}$ and $\mathrm{Ni}$ into the core, which is assumed to contain no light element. No other elements were considered and the initial $\mathrm{Na}$ concentrations were normalised to $20 \%$ of the chondritic value to account for volatility. The primitive Earth's mantle composition determined by Palme and O'Neill [2004] is shown for comparison. Chondrite-based estimates of silicate Earth compositions have $\mathrm{Mg} / \mathrm{Si}$ ratios that are lower than any petrological estimates for this ratio within the BSE or upper mantle [Allegre et al., 1995; McDonough and Sun, 1995; Workman and Hart, 2005; O'Neill and Palme, 1998]. The resulting upper mantle normative mineral contents are olivine poor and in the case of high enstatite chondrites (EHS) become quartz normative. None of the compositions approach fertile mantle xenoliths, which have normative olivine contents of $\sim 60 \mathrm{wt} \%$. $\mathrm{CV}$ and $\mathrm{CO}$ chondrite compositions match many of the major element concentrations but are still $\sim 3-4 \mathrm{wt} \% \mathrm{SiO}_{2}$ enriched/MgO depleted relative to the BSE.

The apparently high $\mathrm{Mg} / \mathrm{Si}$ ratio of the upper mantle raises three possibilities that are not mutually exclusive; that is, the bulk Earth has a superchondritic $\mathrm{Mg} / \mathrm{Si}$ ratio, significant Si entered the Earth's core, or some region of the mantle has a lower $\mathrm{Mg} / \mathrm{Si}$ ratio than the upper mantle. The first possibility, that the Earth has a higher $\mathrm{Mg} / \mathrm{Si}$ ratio than any chondrite or the solar photosphere, is quite plausible given that this ratio varies among chondrites.

Table 18.1 Chondrite-based BSE compositions, upper and lower mantle mineralogy, and core mass.

\begin{tabular}{|c|c|c|c|c|c|c|c|c|c|c|}
\hline & Earth & $\mathrm{Cl}$ & $\mathrm{CM}$ & $\mathrm{CO}$ & $\mathrm{CV}$ & $\mathrm{H}$ & $\mathrm{L}$ & LL & $\mathrm{EH}$ & EL \\
\hline $\mathrm{SiO}_{2}$ & 45.0 & 49.5 & 49.1 & 48.0 & 47.8 & 51.9 & 52.5 & 52.6 & 57.9 & 54.4 \\
\hline $\mathrm{TiO}_{2}^{2}$ & 0.2 & 0.2 & 0.2 & 0.2 & 0.2 & 0.1 & 0.1 & 0.1 & 0.1 & 0.1 \\
\hline $\mathrm{Cr}_{2} \mathrm{O}_{3}$ & 0.38 & 0.8 & 0.8 & 0.7 & 0.8 & 0.8 & 0.8 & 0.7 & 0.7 & 0.6 \\
\hline $\mathrm{Al}_{2} \mathrm{O}_{3}$ & 4.45 & 3.5 & 4.0 & 3.8 & 4.7 & 3.1 & 3.1 & 2.9 & 2.5 & 2.7 \\
\hline $\mathrm{FeO}$ & 8.05 & 8.1 & 8.1 & 8.1 & 8.1 & 8.1 & 8.1 & 8.1 & 8.1 & 8.1 \\
\hline $\mathrm{MgO}$ & 37.8 & 34.8 & 34.5 & 36.0 & 34.4 & 33.3 & 32.8 & 33.0 & 28.5 & 32.0 \\
\hline $\mathrm{CaO}$ & 3.55 & 2.8 & 3.2 & 3.1 & 3.8 & 2.5 & 2.4 & 2.4 & 1.9 & 1.9 \\
\hline $\mathrm{Na}_{2} \mathrm{O}^{\mathrm{a}}$ & 0.36 & 0.3 & 0.2 & 0.2 & 0.1 & 0.3 & 0.3 & 0.2 & 0.3 & 0.2 \\
\hline Total & 99.8 & 100.0 & 100.0 & 100.0 & 100.0 & 100.0 & 100.0 & 100.0 & 100.0 & 100.0 \\
\hline \multicolumn{11}{|c|}{ Upper mantle normative mineralogy } \\
\hline Olivine & 54 & 31 & 30 & 38 & 38 & 18 & 15 & 15 & Quartz & 6 \\
\hline Opx & 23 & 53 & 51 & 44 & 44 & 68 & 73 & 73 & Norm. & 86 \\
\hline Cpx & 20 & 14 & 15 & 15 & 15 & 11 & 10 & 9 & & 6 \\
\hline Spinel & 3 & 3 & 3 & 3 & 3 & 2 & 2 & 2 & & 2 \\
\hline \multicolumn{11}{|c|}{ Lower mantle normative mineralogy } \\
\hline Bdg & 80 & 90 & 89 & 86 & 85 & 96 & 95 & 95 & 85 & 92 \\
\hline Fper & 13 & 5 & 6 & 8 & 8 & 0 & 0 & 0 & 0 & 0 \\
\hline $\mathrm{Ca}-\mathrm{Pv}$ & 6 & 5 & 5 & 5 & 7 & 4 & 4 & 4 & 3 & 3 \\
\hline $\mathrm{SiO}_{2}$ & 0 & 0 & 0 & 0 & 0 & 0 & 1 & 1 & 12 & 5 \\
\hline Core & 32 & 26 & 25 & 23 & 23 & 26 & 19 & 16 & 30 & 20 \\
\hline
\end{tabular}

All values in weight percent. Primitive Earth's mantle composition from O’Neill and Palme [1998], chondrite compositions from Wasson and Kallemeyn [1988]. Abbreviations: Bdg, bridgmanite; Fper, ferropericlase; $\mathrm{Ca}-\mathrm{Pv}, \mathrm{CaSiO}_{3}$ perovskite. Except for Earth the calculated size of the core is solely based on the available Fe and $\mathrm{Ni}$ in the meteorite composition and ignores any light element.

a Initially normalized to $20 \%$ of the chondrite concentrations. 
Redistribution of forsterite $\left(\mathrm{Mg}_{2} \mathrm{SiO}_{4}\right)$ that had partially condensed from solar nebula gas has been one mechanism proposed to explain this [Larimer and Anders, 1970]. Earth could have formed from material that was, on average, enriched in $\mathrm{Mg}_{2} \mathrm{SiO}_{4}$ compared to any chondrite. As this fractionation may have only involved forsterite, an otherwise quite pure mineral, it would be difficult to then constrain the bulk Earth $\mathrm{Mg} / \mathrm{Si}$ ratio via element concentrations calculated from cosmochemical observations. However, it has recently been proposed that concurrent isotopic fractionation between condensing forsterite and nebula gas occurred, which caused variations in the ${ }^{30} \mathrm{Si} /{ }^{28} \mathrm{Si}$ ratio observed among terrestrial planets and meteorites [Dauphas et al., 2015]. Dauphas et al. [2015] provide good evidence for this by demonstrating a clear and predictable correlation between the ${ }^{30} \mathrm{Si} /{ }^{28} \mathrm{Si}$ and $\mathrm{Mg} / \mathrm{Si}$ ratios of chondritic meteorites. They constrain the bulk Earth $\mathrm{Mg} / \mathrm{Si}$ ratio using this trend from the seemingly constant ${ }^{30} \mathrm{Si} /{ }^{28} \mathrm{Si}$ ratio of the mantle and accounting for the fact that some Si likely also entered the core. The resulting bulk Earth $\mathrm{Mg} / \mathrm{Si}$ ratio is higher than any chondrite, in agreement with petrological estimates.

Silicon partitioning into the core has often been proposed to explain the apparent superchondritic $\mathrm{Mg} / \mathrm{Si}$ ratio of the mantle [Allegre et al., 1995; McDonough and Sun, 1995; O'Neill and Palme, 1998] and it is in line with geophysical observations that the core is $5-10 \%$ less dense than expected for pure iron-nickel liquid [Birch, 1952; Poirier, 1994]. In order to obtain an Earth-like $\mathrm{Mg} / \mathrm{Si}$ ratio from the chondrite-based mantle compositions shown in Table 18.1 would require between $5 \mathrm{wt} \%(\mathrm{CV})$ and $20 \mathrm{wt} \%$ (EH) Si to have separated into the core. The higher bulk Earth $\mathrm{Mg} / \mathrm{Si}$ ratio determined by Dauphas et al. [2015] from the $\mathrm{BSE}{ }^{30} \mathrm{Si} /{ }^{28} \mathrm{Si}$ ratio implies that $\sim 3.6 \mathrm{wt} \% \mathrm{Si}$ exists in the core. Although the uncertainties on this estimate are high $(+6.0 /-3.6 \mathrm{wt} \%)$, this relatively low value is in much better agreement with more recent mineral physics estimates for the Si content based on the core's density and seismic velocity [Antonangeli et al., 2010; Badro et al., 2014].

It would seem, from the above arguments, that models requiring a lower $\mathrm{Mg} / \mathrm{Si}$ ratio, in part or all of the lower mantle, to explain the upper mantle superchondritic $\mathrm{Mg}$ / $\mathrm{Si}$ ratio are becoming increasingly redundant. Given the large uncertainties, however, in both mineral physics estimates for the silicon content of the core and cosmochemical estimates for the bulk earth $\mathrm{Mg} / \mathrm{Si}$ ratio, such models cannot yet be completely refuted. If the $\mathrm{Mg} / \mathrm{Si}$ ratio of the lower mantle were lower, this would be manifest as a raised bridgmanite to ferropericlase ratio, as shown by the normative lower mantle mineralogies calculated in Table 18.1. One quite appealing process to achieve this would be as a result of fractional crystallization and settling of bridgmanite from a global magma

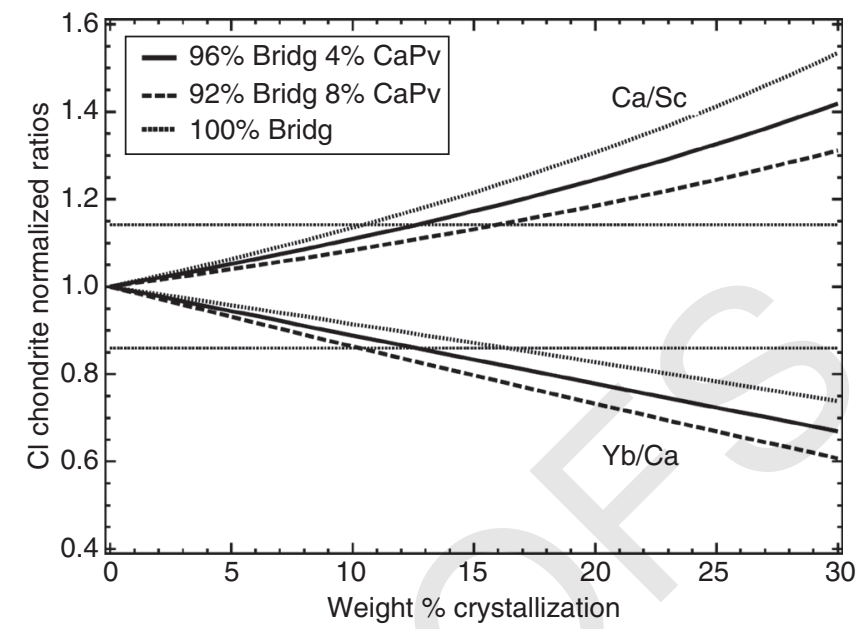

Figure 18.1 Chondrite-normalized $\mathrm{Ca} / \mathrm{Sc}$ and $\mathrm{Yb} / \mathrm{Ca}$ ratios of the residual liquid as a function of crystallization of bridgmanite and $\mathrm{CaSiO}_{3}$ perovskite from a magma ocean. Horizontal lines indicate the uncertainty on both element ratios in the upper mantle. Solid, dashed, and dotted lines show the effect of different proportions of bridgmanite and $\mathrm{CaSiO}_{3}$ perovskite in the fractionating assemblage.

ocean during accretion [Agee and Walker, 1988]. The formation of the moon testifies to the fact that toward the end of accretion the Earth was involved in at least one giant impact, which would have melted a large proportion, if not all, of Earth's mantle [Canup, 2004; Carlson et al., 2014]. As the magma ocean cooled, bridgmanite would have been the liquidus phase throughout much of the lower mantle [Ito et al., 2004; Walter et al., 2004; Andrault et al., 2011; Liebske and Frost, 2012]. Crystallization and settling of bridgmanite from an initially chondritic magma ocean could, in principle, have driven up the $\mathrm{MgO}$ content of the residual liquid, which would ultimately crystallize to form the upper mantle. In detail, however, mass balance calculations based on experimentally determined liquidus phase compositions fail to find a crystallization sequence that can derive the composition of the upper mantle in this way [Walter et al., 2004; Jackson et al., 2014]. Furthermore, a number of well-constrained chondritic element ratios apparent in the upper mantle would not have been preserved if more than $\sim 10 \%$ bridgmanite fractionation occurred from an initially chondritic magma ocean, as shown in Figure 18.1 [Kato et al., 1988; Walter et al., 2004; Corgne et al., 2005; Liebske et al., 2005]. It should be noted, however, that both the liquidus-phase composition and trace element partitioning arguments are based around experiments performed at conditions that correspond only to the very top of the lower mantle.

A number of seismological studies have argued for the existence of large-scale $(>1000 \mathrm{~km})$ heterogeneities in the mantle at $>2400 \mathrm{~km}$ depths [Su et al., 1994; 
Li and Romanowicz, 1996; Ni et al., 2002]. Due to their seismic properties, these heterogeneities have been termed large low-shear-velocity provinces (LLSVPs). Two antipodal provinces have been identified beneath Africa and the Pacific, and based on paleomagnetic reconstructions, it has been proposed [Torsvik et al., 2008] that the majority of hot spots with a suggested deep-mantle origin derive from the edges of these anomalies [but see also Austermann et al., 2014]. The relatively small size of these anomalies means that they could have originally formed by fractional crystallization of bridgmanite, with or without Ca-perovskite, from a global magma ocean without upsetting known chondritic ratios in the residual liquid that formed the upper mantle [Jackson et al., 2014]. However, if LLSVPs have remained at the base of the mantle for the timescales proposed by plume reconstructions, then they are probably composed of material denser than the average mantle at these depths. The most plausible explanation for this would be as a result of iron enrichment, but as the available evidence indicates that the magma ocean itself should be more enriched in iron than the crystallizing phases [Andrault et al., 2011, 2012; Nomura et al., 2011], it probably makes more sense if LLSVPs formed from the crystallization of a dense residual basal magma ocean, rather than crystal settling from a global magma ocean.

In summary, although the hypothesis that the lower mantle may be different in major element composition from the upper mantle has been eroded in recent years by geophysical observations of slabs entering the lower mantle, the prospect cannot be excluded and there are mechanisms by which a chemically distinct lower mantle could have been created and at least partially preserved over geological history. As proposed, the only way to categorically exclude this possibility is to compare seismic velocities for the lower mantle with mineral physical models based on a given chemical composition. Recently such an approach was used to argue that the lower mantle is indeed chemically distinct, with a $\mathrm{Mg} / \mathrm{Si}$ ratio closer to that of carbonaceous chondrites [Murakami et al., 2012]. If such comparisons are to be meaningful, however, some account must be taken of the fact that the elasticity of mantle minerals changes as a function of their composition. Building a realistic model for the effects of composition on the seismic velocities of lower mantle minerals remains a key goal in mineral physics.

\subsection{MINERALOGY AND CRYSTAL CHEMISTRY OF THE LOWER MANTLE}

If the entire mantle is isochemical, then the lower mantle should be composed of bridgmanite, ferropericlase, and $\mathrm{CaSiO}_{3}$ perovskite in the approximate proportions given for the Earth model in Table 18.1 Although there are a large number of estimates for the composition of the BSE based on peridotite rocks and mantle melting scenarios such as the pyrolite model [Ringwood, 1975; McDonough and Sun, 1995; O'Neill and Palme, 1998; Walter, 2003], across the range of these ultramafic compositions the predicted proportion of bridgmanite in the lower mantle changes only between 80 and $82 \mathrm{wt} \%$.

$\mathrm{CaSiO}_{3}$ perovskite exsolves from garnet at depths between 500 and $660 \mathrm{~km}$ in the transition zone [Irifune and Tsuchiya, 2007; Saikia et al., 2008]. Bridgmanite is formed through two reactions. The first is dissociation of $(\mathrm{Mg}, \mathrm{Fe})_{2} \mathrm{SiO}_{4}$ ringwoodite into ferropericlase and bridgmanite and is responsible for the $660 \mathrm{~km}$ seismic discontinuity. Due to the similarity in $\mathrm{Fe}-\mathrm{Mg}$ partitioning across the transformation, it should take place over a narrow pressure interval equivalent to $<2 \mathrm{~km}$ in depth [Ito and Takahashi, 1989; Ito et al., 1990], which is consistent with seismic observations of short-period reflected and converted phases [Kind and $\mathrm{Li}, 2007$ ]. The second bridgmanite formation mechanism is via garnet breakdown, which occurs over a $\sim 100 \mathrm{~km}$ interval at the top of the lower mantle. Close to the transition zone-lower mantle boundary, $\mathrm{MgSiO}_{3}$ bridgmanite exsolves, lowering the $\mathrm{Mg}$ majoritic component of the residual garnet. Growth continues as the solution of $\mathrm{Al}_{2} \mathrm{O}_{3}$ in bridgmanite increases [Irifune, 1994; Nishiyama and Yagi, 2003; Irifune and Tsuchiya, 2007]. The preservation of garnet in the uppermost lower mantle may be responsible for slightly lower velocities than otherwise expected.

Further changes in mineral assemblage for a BSE bulk composition are limited to the base of the mantle. At depths greater than $2600 \mathrm{~km}$ bridgmanite may transform to the post-perovskite phase [Murakami et al., 2004; Irifune and Tsuchiya, 2007], although the positive and relatively shallow Clausius-Clapeyron slope of this transformation may limit the stability of this phase to only the coldest regions of the lowermost mantle. High thermal gradients may lead to double-crossings of the bridgmanite-postperovskite transition [Hernlund et al., 2005]. Preliminary results indicate that at about $2000 \mathrm{~km}$ a relatively $\mathrm{FeSiO}_{3}$-rich phase, termed $\mathrm{H}$ phase, may exsolve from bridgmanite, leaving the latter strongly depleted in Fe [Zhang et al., 2014].

\subsection{LOWER MANTLE MINERAL COMPOSITIONS}

The dominant lower mantle minerals are all solid solutions. Bridgmanite is dominated by the $\mathrm{MgSiO}_{3}$ end member but contains $\sim 10$ mole $\% \mathrm{FeSiO}_{3}, \mathrm{FeAlO}_{3}$ and $\mathrm{AlAlO}_{3}$ end members. Ferropericlase in addition to $\mathrm{MgO}$ and $\mathrm{FeO}$ contains $\sim 1$ wt $\% \mathrm{SiO}_{2}$ and $\mathrm{Al}_{2} \mathrm{O}_{3}$ and contains the lower mantle compliment of $\mathrm{Na}_{2} \mathrm{O} . \mathrm{CaSiO}_{3}$ perovskite is relatively pure but also contains $\sim 1$ wt $\% \mathrm{Al}_{2} \mathrm{O}_{3}$, $\mathrm{MgO}$, and $\mathrm{FeO}$; furthermore its very strong affinity for large cations means that it also hosts the lower mantle's compliment of heat-producing elements, $\mathrm{U}, \mathrm{Th}$, and $\mathrm{K}$. 
Once garnet has transformed to bridgmanite, the proportions of these three minerals should remain relatively constant throughout the lower mantle for a given bulk composition [Irifune and Tsuchiya, 2007]. The proportion of $\mathrm{CaSiO}_{3}$ is fixed by the $\mathrm{CaO}$ content of the bulk composition and the proportions of bridgmanite and ferropericlase by the remaining $\mathrm{SiO}_{2}$ and $\mathrm{Al}_{2} \mathrm{O}_{3}$. The only major variation expected to occur is in the distribution of $\mathrm{Fe}$ and $\mathrm{Mg}$ between the two dominant minerals. This variation is complicated by the fact that, at least in experiments, bridgmanite contains subequal proportions of both $\mathrm{Fe}^{2+}$ and $\mathrm{Fe}^{3+}$ cations (McCammon, 1997; Lauterbach et al., 2000]. Furthermore, $\mathrm{Fe}^{2+}$ in both dominant phases and possibly $\mathrm{Fe}^{3+}$ in bridgmanite may go through a high spin-low spin transformation as pressures increase, which may also influence the distribution of both Fe components [Lin et al., 2013; Badro, 2014]. The smaller volume of low-spin iron (ferric and ferrous) and the redistribution of iron during spin transitions can potentially influence both the densities and seismic wave velocities with depth in the lower mantle. In particular, the distribution of iron will influence both the $\mathrm{Fe}^{2+}$ and $\mathrm{Fe}^{3+}$ contents of bridgmanite, which have also been shown to influence the elasticity and inferred seismic velocity of this mineral [Boffa Ballaran et al., 2012; Chantel et al., 2012; Wang et al., 2015].
The exchange of $\mathrm{Fe}^{2+}$ and $\mathrm{Mg}$ between bridgmanite and ferropericlase can be described using the equilibrium

$$
\underset{\text { ferropericlase }}{\mathrm{FeO}}+\underset{\text { bridgmanite }}{\mathrm{MgSiO}_{3}} \leftrightarrow \underset{\text { ferropericlase }}{\mathrm{MgO}}+\underset{\text { bridgmanite }}{\mathrm{FeSiO}_{3}}
$$

and the corresponding exchange coefficient $K_{D}$,

$$
K_{D}=\frac{X_{\mathrm{FeSiO}_{3}}^{\mathrm{Bdg}} X_{\mathrm{MgO}}^{\mathrm{Fper}}}{X_{\mathrm{MgSiO}_{3}}^{\mathrm{Bdg}} X_{\mathrm{FeO}}^{\mathrm{Fper}}},
$$

where $X_{\mathrm{FeSiO}_{3}}^{\mathrm{Bdg}}$ is, for example, the mole fraction of the $\mathrm{FeSiO}_{3}$ end member in bridgmanite, which would equate to the molar cation ratio $\mathrm{Fe}^{2+} /\left(\mathrm{Fe}^{2+}+\mathrm{Mg}\right)$. However, because a significant proportion of the $\mathrm{Fe}$ in bridgmanite is $\mathrm{Fe}^{3+}$ in systems which also contain $\mathrm{Al}$ and the majority of studies are not able to analyse the $\mathrm{Fe}^{3+} / \Sigma \mathrm{Fe}$ ratio, many studies define an apparent $\mathrm{Fe}-\mathrm{Mg}$ exchange $K_{D}(\mathrm{app})$ where $X_{\mathrm{FeSiO}_{3}}^{\mathrm{Brid}}=\left(\mathrm{Fe}^{2+}+\mathrm{Fe}^{3+}\right) /\left(\mathrm{Fe}^{2+}+\mathrm{Fe}^{3+}+\mathrm{Mg}\right)$. Figure 18.2 shows determinations for $K_{D}(\mathrm{app})$ from recent studies as a function of pressure. The experiments are broken into two groups, those that have studied an ultramafic composition in a natural system, most of these have used a pyrolite composition, and experiments performed with

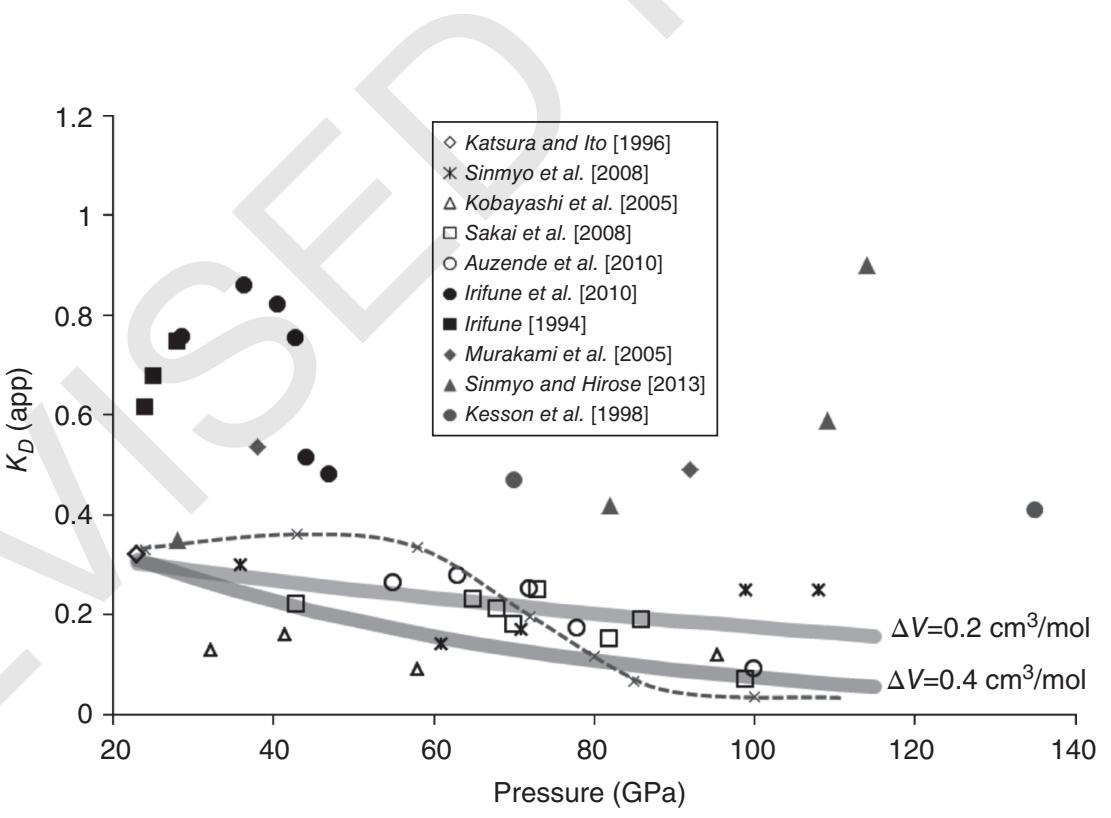

Figure 18.2 Apparent Fe-Mg exchange coefficient (apparent from electron microprobe analyses, i.e., all Fe is assumed to be FeO) plotted as a function of pressure for experiments performed using a mantle olivine starting material (open symbols and crosses) and pyrolite (black filled symbols-from multianvil experiments, filled grey symbols from laser-heated diamond anvil cell experiments). The two curves are thermodynamic calculations employing the model of Nakajima et al. [2012] but assuming different volume changes for the exchange equilibrium (18.1). The thickness of each line equates to a temperature variation of $\pm 200^{\circ} \mathrm{C}$ in the calculation. The dashed grey line is calculated for a mantle olivine bulk composition assuming a high-spin to low-spin $\mathrm{Fe}^{2+}$ transition in ferropericlase occurs over a pressure interval between 40 and $90 \mathrm{GPa}$. 
mantle olivine, $\left(\mathrm{Fe}_{0.1}, \mathrm{Mg}_{0.9}\right)_{2} \mathrm{SiO}_{4}$, as a starting material. It should be recognized that $K_{D}(\mathrm{app})$ is expected to vary with bulk Fe concentration, pressure, and temperature [Nakajima et al., 2012] but the expected variations between the studies for a given starting material should be small. As will be discussed later, $K_{D}(\mathrm{app}) \approx K_{D}$ for samples formed from olivine starting materials, but this is not the case for pyrolite compositions mainly due to the $\mathrm{Al}$ content of bridgmanite promoting the presence of $\mathrm{Fe}^{3+}$.

The majority of values of $K_{D}(\mathrm{app})$ for bridgmanite and periclase produced from olivine starting materials indicate a decrease in $K_{D}(\mathrm{app})$ with pressure. Studies above $25 \mathrm{GPa}$ are performed in the laser-heated diamond anvil cell and in detail many of the different studies are in poor agreement. Shown for comparison in Figure 18.2 are two curves calculated for a mantle olivine composition using a thermodynamic treatment of the exchange equilibrium (18.1). This model was derived by fitting experimental data collected at $24 \mathrm{GPa}$ as a function of the $\mathrm{Fe} /(\mathrm{Fe}+\mathrm{Mg})$ ratio to the equation

$R T \ln K_{D}=-\Delta G_{(18.1)}^{o}+W_{\mathrm{FeMg}}^{\mathrm{Bdg}}\left(2 X_{\mathrm{Fe}}^{\mathrm{Bdg}}-1\right)+W_{\mathrm{FeMg}}^{\mathrm{Fper}}\left(1-2 X_{\mathrm{Fe}}^{\mathrm{Fper}}\right)$,

where $R$ is the gas constant, $W_{\mathrm{FeMg}}^{\mathrm{Bdg}}$ and $W_{\mathrm{FeMg}}^{\mathrm{Fper}}$ are Margules interaction parameters for bridgmanite and ferropericlase that describe nonideal $\mathrm{Fe}$ and $\mathrm{Mg}$ mixing, and $\Delta G_{(18.1)}^{o}$ is the standard state Gibbs free energy of equilibrium (18.1) at the pressure and temperature of interest. Values determined for $\Delta G_{(1)}^{o}$ can be simply described by the expression

$$
\Delta G_{(18.1)}^{\circ}=\Delta H^{\circ}-T \Delta S^{\circ}+P \Delta V^{\circ}
$$

where $\Delta H^{\circ}, \Delta S^{\circ}$ and $\Delta V^{\circ}$ are the standard state enthalpy, entropy, and volume changes of equilibrium (18.1), which are all considered to be independent of pressure and temperature. Equation (18.3) has been fitted to data collected in the $\mathrm{FeO}-\mathrm{MgO}-\mathrm{SiO}_{2}$ system at $24 \mathrm{GPa}$, where experiments also contained metallic iron to ensure that $K_{D}(\mathrm{app}) \approx K_{D}$ [Nakajima et al., 2012]. The equation can then be extrapolated to higher pressures by making assumptions concerning the magnitude of $\Delta V^{\circ}$, as shown in Figure 18.2. The majority of olivine results are consistent with a $\Delta V^{\circ}$ of $0.2 \mathrm{~cm}^{3} / \mathrm{mol}$, although three studies, which are in good agreement at $100 \mathrm{GPa}$, would require a $\Delta V^{\circ}$ of $\sim 0.4 \mathrm{~cm}^{3} /$ mol [Kobayashi et al., 2005; Sinmyo et al., 2008; Sakai et al., 2009]. A $\Delta V^{\circ}$ of $0.2 \mathrm{~cm}^{3} / \mathrm{mol}$ would be consistent with mineral physics estimates for this volume change based on ambient volume and elasticity data of the end members once the uncertainties are considered $[X u$ et al. 2008]. The mineral physical data and model of $X u$ et al. [2008] actually predict a small but negative value of
$\Delta V^{o}$ but a value of $0.2 \mathrm{~cm}^{3} / \mathrm{mol}$ would still be within the uncertainties. A value of $0.4 \mathrm{~cm}^{3} / \mathrm{mol}$ is probably too large to be explained by existing volume and elasticity measurements, although many of the thermoelastic properties have not been measured at mantle temperatures. An alternative explanation for data lying along the $0.4 \mathrm{~cm}^{3} / \mathrm{mol}$ trend is that the $\mathrm{Fe}^{2+}$ component in ferropericlase undergoes a high spin-low spin electronic transition [Burns, 1993; Badro et al., 2003].

It is relatively straightforward to make a simple estimate for the effect of a ferropericlase $\mathrm{Fe}^{2+}$ spin transition on $\mathrm{Fe}-\mathrm{Mg}$ exchange by using experimental estimates for the proportion of the high-spin and low-spin components as a function of pressure [e.g., Speziale et al., 2007] and by assuming that they mix ideally. If $n$ is the proportion of low-spin $\mathrm{Fe}^{2+}$, then the Gibbs free energy of the $\mathrm{FeO}$ component as it crosses the transition can be determined from

$$
G_{P, T}=n G_{\mathrm{LS}}^{o}+(1-n) G_{\mathrm{HS}}^{o}+R T[n \ln (n)+(1-n) \ln (1-n)],
$$

where $G_{\mathrm{LS}}^{o}$ and $G_{\mathrm{HS}}^{o}$ are the Gibbs free energies of the low-spin and high-spin $\mathrm{FeO}$ components. Using experimental values of $n$ as a function of pressure, the derivative of equation (18.5) with respect to $n$ can be used to determine the difference in Gibbs free energy between high-spin and low-spin FeO, i.e.,

$$
G_{\mathrm{LS}}^{o}-G_{\mathrm{HS}}^{o}=R T \ln \left(\frac{1}{n}-1\right) .
$$

Using these differences at each pressure and values of $G_{\mathrm{HS}}^{o}$ determined using a thermodynamic database [Xu et al., 2008], values of $G_{\mathrm{LS}}^{o}$ can be calculated and used in equation (18.5) to determine the Gibbs free energy of $\mathrm{FeO}$ across the transformation. Then $\Delta G_{(18.1)}^{\circ}$ can be calculated across the transition using further thermodynamic data for the remaining mineral end Members in equilibrium (18.1) and $K_{D}$ is then determined using equation (18.3) assuming a $\left(\mathrm{Fe}_{0.1}, \mathrm{Mg}_{0.9}\right)_{2} \mathrm{SiO}_{4}$ bulk composition. In Figure 18.2 the results of such a calculation are shown by employing the experimental data for $n$ versus $P$ from Speziale et al. [2007], who determined the mixed state transition interval in ferropericlase to be between 40 and $90 \mathrm{GPa}$. The elasticity data used by Xu et al. [2008] actually predict a small negative $\Delta V_{(18.1)}^{\circ}$ before the spin transition, which results in an initial increase in $K_{D}$, but this is reversed as soon as the transition commences. As stated previously, values up to $0.2 \mathrm{~cm}^{3} / \mathrm{mol}$ would be consistent with the elasticity data within its uncertainties. In general, however, the change in $K_{D}$ predicted for the spin transition is consistent in magnitude with that seen in some studies and reproduces the low values at $100 \mathrm{GPa}$ shown by three 
different studies [Kobayashi et al., 2005; Auzende et al., 2008; Sakai et al., 2009]. The shape of the curve can be manipulated by changing the assumptions. The pressure of onset and the interval of the transition will be a major influence, and there is a range in the experimental estimates for both [Lin et al., 2013; Badro, 2014]. In the calculation $W_{\mathrm{FeMg}}^{\mathrm{Fper}}$ is held constant across the transition, which is certainly unrealistic. Reducing the magnitude of $W_{\mathrm{FeMg}}^{\mathrm{Fper}}$ as a function of $1-n$ shifts the curve to lower pressures by $\sim 5 \mathrm{GPa}$. Interaction terms involving the low-spin $\mathrm{Fe}^{2+}$ component have been ignored but are likely to be smaller than $W_{\mathrm{FeMg}}^{\mathrm{Fper}}$ because low-spin Fe should be closer to $\mathrm{Mg}^{2+}$ in size. A major prediction of the model, however, is that for mantle olivine bulk compositions between 24 and $100 \mathrm{GPa}$ the ferropericlase $\mathrm{Fe} /(\mathrm{Fe}+\mathrm{Mg})$ ratio increases from $\sim 0.15$ to $\sim 0.19$, while that of bridgmanite decreases from $\sim 0.05$ to $\sim 0.01$. These changes are most likely sufficient to influence calculated velocities and densities for the lower mantle. As detailed below, these changes are probably larger than those taking place in the BSE (pyrolite) composition mantle, where a significant portion of the $\mathrm{Fe}$ ends up as $\mathrm{Fe}^{3+}$ in bridgmanite. Nevertheless, the loss of $\mathrm{Fe}^{2+}$ from bridgmanite may reduce the probability of forming the proposed $\mathrm{H}$ phase [Zhang et al., 2014].

Although this simplistic treatment reproduces behavior seen in some experimental data for $\left(\mathrm{Fe}_{0.1}, \mathrm{Mg}_{0.9}\right)_{2} \mathrm{SiO}_{4}$ starting compositions, the resulting pressure dependence of the data is not in agreement with all studies. Figure 18.3 shows experimental $\mathrm{Fe}-\mathrm{Mg}$ partitioning results obtained in the multianvil apparatus by Tange et al. [2009] using an olivine composition starting material but with a much higher $\mathrm{Fe} /(\mathrm{Fe}+\mathrm{Mg})$ ratio than in the studies shown in Figure 18.2. These data were collected between 22 and $43 \mathrm{GPa}$ at $2273 \mathrm{~K}$ and are compared with model calculations described above assuming a constant $\Delta V_{(18.1)}^{\circ}$ of $0.4 \mathrm{~cm}^{3} / \mathrm{mol}$. As stated previously, a volume change of this magnitude would appear to be inconsistent with the end-member volumes and equation-of-state data [Xu et al., 2008]. On the other hand, an iron spin transition in ferropericlase starting at $\sim 22 \mathrm{GPa}$ is probably also inconsistent with the prediction that higher $\mathrm{FeO}$ contents should push this transition to much higher pressures [Lin et al., 2013; Badro, 2014]. Such inconsistencies and uncertainties in the pressure range over which the spin transition occurs currently make it difficult to unify the existing experimental data into a single model.

The problems that exist in understanding results in simplified olivine systems are somewhat trivial in comparison to those encountered for studies employing natural pyrolite (i.e., BSE) compositions. As shown in Figure 18.2, pyrolite $K_{D}(\mathrm{app})$ values are not only higher than for olivine compositions but also are seen to increase up to $\sim 40 \mathrm{GPa}$ and then decrease quite sharply.

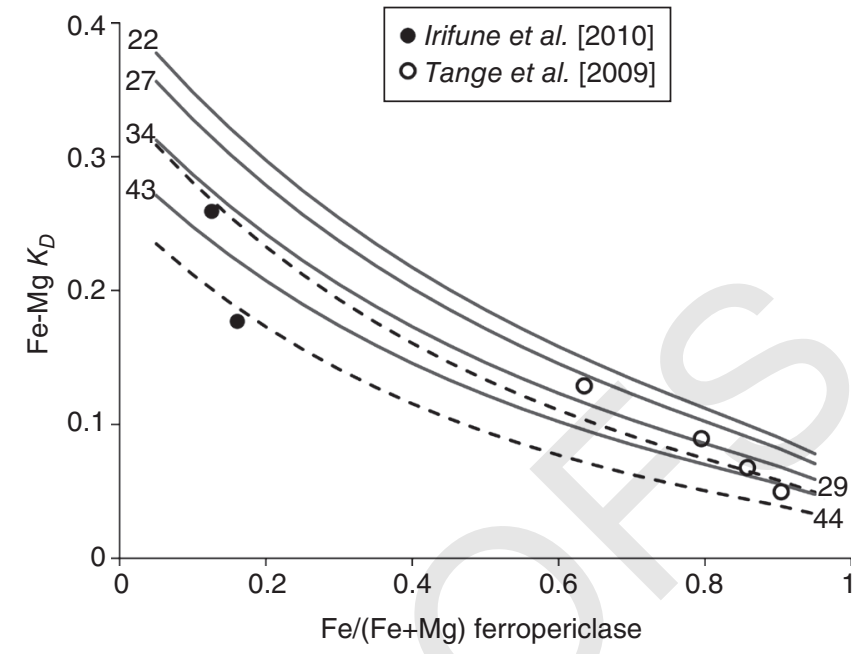

Figure 18.3 Bridgmanite/ferropericlase $\mathrm{Fe}^{2+}-\mathrm{Mg}$ exchange coefficients determined at $2273 \mathrm{~K}$ and between 22 and $43 \mathrm{GPa}$ by Tange et al. [2009] in the MgO-FeO-SiO ${ }_{2}$ system are compared with (grey) curves calculated at the same conditions using the model of Nakajima et al. [2012]. To fit the experimental data the $\Delta V$ of the Fe-Mg exchange equilibrium must be assumed to be $0.4 \mathrm{~cm}^{3} / \mathrm{mol}$. The $\mathrm{Fe}^{2+}-\mathrm{Mg} K_{D}$ has also been estimated for data reported by Irifune et al. [2010] from experiments performed on a natural pyrolite composition at $29 \mathrm{GPa}$ and $1873 \mathrm{~K}$ and $44 \mathrm{GPa}$ and $2073 \mathrm{~K}$ using the reported bridgmanite $\mathrm{Fe}^{3+} / \Sigma$ Fe ratios. These data also fit the same model with the same $\Delta V$ (as shown by the dashed lines).

At $>50 \mathrm{GPa}$ there is poor agreement between studies. As shown in Figure 18.4a, the initial excursion to high values of $K_{D}(\mathrm{app})$ between 22 and $28 \mathrm{GPa}$ is a strong function of the bridgmanite $\mathrm{Al}$ content, which increases over this pressure range due to the breakdown of the mineral garnet [Irifune, 1994; Wood and Rubie, 1996; Nishiyama and Yagi, 2003]. The increase in $K_{D}$ (app) can be mainly attributed to an increase in the bulk Fe content of bridgmanite. Measurements using Mössbauer and electron energy loss spectroscopy have shown that this additional $\mathrm{Fe}$ is predominantly $\mathrm{Fe}^{3+}$ [McCammon, 1997; Lauterbach et al., 2000; Frost and Langenhorst, 2002; Mc Cammon et al., 2004]. Figure $18.4 \mathrm{~b}$ shows the proportion of $\mathrm{Fe}^{3+}$ cations measured in bridgmanite as a function of the Al content. The data are shaded to indicate the bulk Fe content. The $\mathrm{Fe}^{3+}$ increases with both $\mathrm{Al}$ and bulk Fe content and the Al dependence at a given bulk Fe content appears to be nonlinear. Bridgmanite $\mathrm{Fe}^{3+}$ contents were determined for samples from 29 and $44 \mathrm{GPa}$ in the study of Irifune et al. [2010] and are also shown in Figure 18.4b. These measurements can be used to calculate the $\mathrm{Fe}^{2+}-\mathrm{Mg}$ exchange coefficient between bridgmanite and ferropericlase, i.e., $K_{D}$, which is also plotted in Figure 18.3. The result from $28 \mathrm{GPa}$ is in good agreement with values of $K_{D}$ determined in Al-free systems at $25 \mathrm{GPa}$ and reproduced by 
(a)

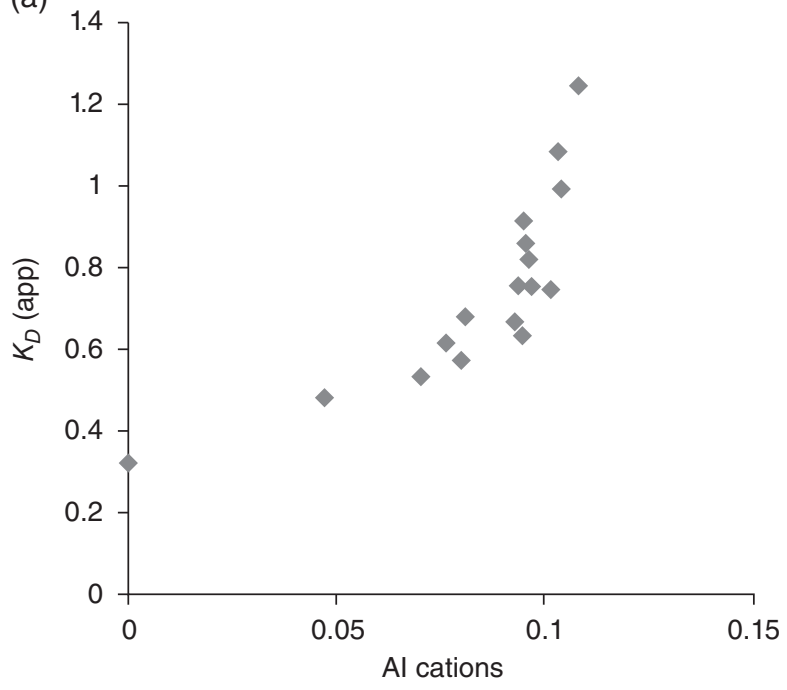

(b)

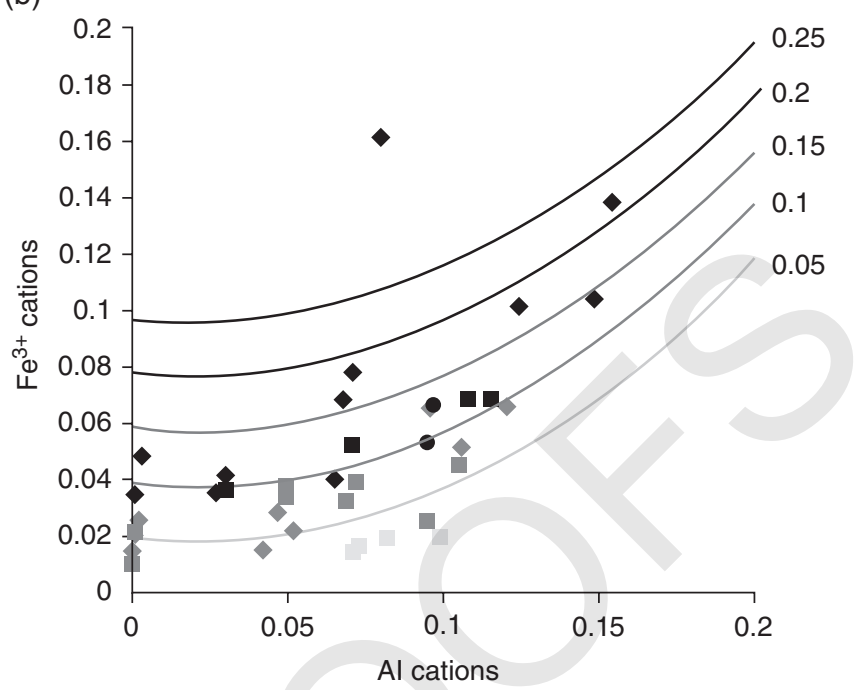

Figure 18.4 (a) Apparent Fe-Mg exchange coefficient between bridgmanite and ferropericlase is shown to be a function of bridgmanite $\mathrm{Al}$ content, in cations per 3 oxygen formula units. The data are from experiments performed between 23 and 29 GPa using pyrolitic bulk compositions, except the Al-free data point for which an olivine starting material was employed [Katsura and Ito, 1996]. (b) Bridgmanite $\mathrm{Fe}^{3+}$ versus $\mathrm{Al}^{3+}$ in cation formula units determined from experiments performed at 25 GPa but including the analyses of Irifune et al. [2010] from 29 and $44 \mathrm{GPa}$ (circles). Data points are shaded to indicate the bulk Fe content, with the shading following the proportions indicated by the empirical model curves derived by Nakajima et al. [2012] that follow the expression $\mathrm{Fe}^{3+}=-0.13 \mathrm{Al}+3.1 \mathrm{Al}^{2}+0.9 \sum \mathrm{Fe}$. Experiments performed in the presence of iron metal or in iron capsules (squares) show similar $\mathrm{Fe}^{3+}$ contents to those performed at more oxidizing conditions (diamonds). Experiments performed at the peridotite solidus show lower but still significant $\mathrm{Fe}^{3+}$ contents.

the model calculation at this pressure. This supports the argument of Nakajima et al. [2012] that the presence of $\mathrm{Al}$ influences the $\mathrm{Fe}^{3+}$ content of bridgmanite but does not strongly influence $\mathrm{Fe}^{2+}$ - $\mathrm{Mg}$ exchange between phases. The value determined at $44 \mathrm{GPa}$ indicates that the precipitous drop in $K_{D}(\mathrm{app})$ that occurs above $40 \mathrm{GPa}$ is caused to a large extent by a more favorable partitioning of $\mathrm{Fe}^{2+}$ into ferropericlase. A consequence of the bulk Fe content of bridgmanite decreasing is that the $\mathrm{Fe}^{3+}$ content also drops, as expected from the relationships outlined in Figure 18.4b. To model this strong decrease in $K_{D}$, a $\Delta V_{(1)}^{\circ}$ of $\sim 0.4 \mathrm{~cm}^{3} / \mathrm{mol}$ is again required. As stated previously, such a high value is in conflict with mineral physics estimates, although given the consistency with the $\Delta V_{(18.1)}^{\circ}$ made using the data of Tange et al. [2009] and some of the diamond anvil cell (DAC) data on olivine, it is hard not to suspect that it is the elasticity data that are in error. The alternative explanation, that this arises from the onset of an Fe spin transition in ferropericlase, seems unlikely as most studies argue for a much higher pressure onset. The start of the transition would need to be at least $10 \mathrm{GPa}$ lower in pressure than that modeled for $\left(\mathrm{Fe}_{0.1}, \mathrm{Mg}_{0.9}\right)_{2} \mathrm{SiO}_{4}$ starting compositions in Figure 18.2, and the onset of this transition is at lower pressure than proposed in many studies [Lin et al., 2013; Badro, 2014].
The effect of this rapid decrease in $K_{D}($ app) is actually smaller than predicted for the spin transition in a mantle olivine bulk composition, because much of the iron remains as $\mathrm{Fe}^{3+}$ in bridgmanite. Between 30 and $50 \mathrm{GPa}$ the $\mathrm{Fe} /$ $(\mathrm{Fe}+\mathrm{Mg})$ ratio of ferropericlase increases from $\sim 0.11$ to $\sim 0.15$, while bridgmanite decreases from $\sim 0.11$ to $\sim 0.08$.

Several studies have proposed that $\mathrm{Fe}^{3+}$ in bridgmanite may also undergo a high spin-low spin crossover [ $\mathrm{Lin}$ et al., 2013]. Experiments appear to indicate that $\mathrm{Fe}^{3+}$ undergoes a spin crossover when it substitutes onto the smaller octahedrally coordinated Si site (B site). This occurs in Al-free bridgmanite and the spin transition takes place between 15 and $50 \mathrm{GPa}$ [Catalli et al., 2010; Hsu et al., 2011]. In Al-bearing perovskite; however, $\mathrm{Fe}^{3+}$ resides almost exclusively on the larger $\mathrm{Mg}$ site (A site), meaning that there is little-high spin $\mathrm{Fe}^{3+}$ on the $\mathrm{B}$ site that could transform. Nevertheless, stabilization of $\mathrm{Fe}^{3+}$ on the $\mathrm{B}$ site as a result of the transition could drive up the $\mathrm{Fe}^{3+}$ occupancy on that site, via the exchange reaction

$$
\mathrm{Fe}_{\mathrm{A}}^{3+, \mathrm{HS}}+\mathrm{Al}_{\mathrm{B}}^{3+} \rightarrow \mathrm{Fe}_{\mathrm{B}}^{3+, \mathrm{LS}}+\mathrm{Al}_{\mathrm{A}}^{3+}
$$

[Grocholski et al., 2009; Catalli et al., 2010; Fujino et al., 2012]. At low temperatures $(\leq 1300 \mathrm{~K})$, the amount of low-spin $\mathrm{Fe}^{3+}$ on the $\mathrm{B}$ site appears to be negligible 
[Glazyrin et al., 2014]. At higher temperatures, the current data are more ambiguous. Mössbauer analysis of a sample of $\mathrm{Mg}_{0.6} \mathrm{Fe}_{0.4} \mathrm{Si}_{0.63} \mathrm{Al}_{0.37} \mathrm{O}_{3}$ bridgmanite before, during, and after laser heating at $1700-1800 \mathrm{~K}$ showed no evidence of low-spin $\mathrm{Fe}^{3+}$ up to $80 \mathrm{GPa}$ [Glazyrin et al., 2014]. In contrast, Mössbauer and $\mathrm{X}$-ray emission spectroscopy on samples of $\mathrm{Mg}_{0.88} \mathrm{Fe}_{0.13} \mathrm{Si}_{0.88} \mathrm{Al}_{0.11} \mathrm{O}_{3}$ and $\mathrm{Mg}_{0.85} \mathrm{Fe}_{0.15} \mathrm{Si}_{0.85} \mathrm{Al}_{0.15} \mathrm{O}_{3}$ synthesized at $\sim 2000 \mathrm{~K}$ appears to indicate significant low-spin $\mathrm{Fe}^{3+}$ after the spin transition [Catalli et al., 2011; Fujino et al., 2012]. Ab initio investigations suggest that temperature plays a key role in stabilizing low-spin $\mathrm{Fe}^{3+}$ [Hsu et al., 2012], but it would seem that more work is required to assess the importance of both composition and temperature on $\mathrm{Fe}^{3+}$ spin state at lower mantle conditions.

\subsection{OXIDATION STATE OF IRON BRIDGMANITE AND ITS IMPLICATIONS}

An important aspect of measured bridgmanite $\mathrm{Fe}^{3+}$ contents is that they appear to be nominally independent of oxygen fugacity. At upper mantle conditions minerals that can accommodate $\mathrm{Fe}^{3+}$ generally have $\mathrm{Fe}^{3+} / \Sigma \mathrm{Fe}$ ratios that are broadly a function of oxygen fugacity [O'Neill et al., 1993; Ballhaus et al., 1991]. At oxygen fugacities compatible with the existence of metallic iron such minerals have $\mathrm{Fe}^{3+} / \Sigma \mathrm{Fe}$ ratios that are below detection limits. Aluminum-bearing bridgmanites synthesized in the presence of metallic iron, however, have been shown to have $\mathrm{Fe}^{3+} / \Sigma \mathrm{Fe}$ ratios similar to those produced at oxygen fugacities buffered by the presence of $\mathrm{Re}$ and $\mathrm{ReO}_{2}$, i.e., $>0.5$ [Lauterbach et al., 2000; Frost et al., 2004]. The $\mathrm{Re}-\mathrm{ReO}_{2}$ buffer has an oxygen fugacity at least $5 \log$ units higher than Fe metal saturation. There appears to be no barrier to the incorporation of $\mathrm{Fe}^{3+}$ in bridgmanite as even $\mathrm{Al}$-free samples have been synthesised containing iron exclusively in this oxidation state [Hummer and Fei, 2012]. The high-pressure multianvil assembly is probably not a closed system to oxygen and likely exerts a relatively oxidizing environment due to the presence of adsorbed $\mathrm{H}_{2} \mathrm{O}$ within the ceramics of the assembly. For this reason the occurrence of $\mathrm{Fe}^{3+}$ in many bridgmanite samples is probably consistent with the ambient oxygen fugacity, which is likely much higher than in the lower mantle. Nevertheless, the presence of iron metal in some of the experiments [Lauterbach et al., 2000; Frost et al., 2004] should ensure that the oxygen fugacity is fixed at the lowest plausible level for the lower mantle as long as equilibrium was achieved. At lower oxygen fugacities than this, iron would be reduced out of bridgmanite. The fact that high $\mathrm{Fe}^{3+} / 2 \mathrm{Fe}$ ratios are still encountered in the bridgmanite samples equilibrated with metallic iron implies that high $\mathrm{Fe}^{3+}$ contents most likely also exist in this mineral in the lower mantle, at least at the conditions equivalent to those at which experiments have been performed.

The relationships shown in Figure 18.4 imply that $\mathrm{Fe}^{3+}$ is likely stabilized within the bridgmanite structure as a result of an energetically favorable coupled substitution with $\mathrm{Al}$. The $\mathrm{Fe}^{3+}$ substitution onto the larger A site is probably charge balanced by Al substitution onto the smaller octahedral B site [Lauterbach et al., 2000; Frost and Langenhorst, 2002]. However, as shown in Figure 18.5, this is not the only trivalent substitution mechanism operating in bridgmanite. Most of the samples, particularly at lower total trivalent cation concentrations and including

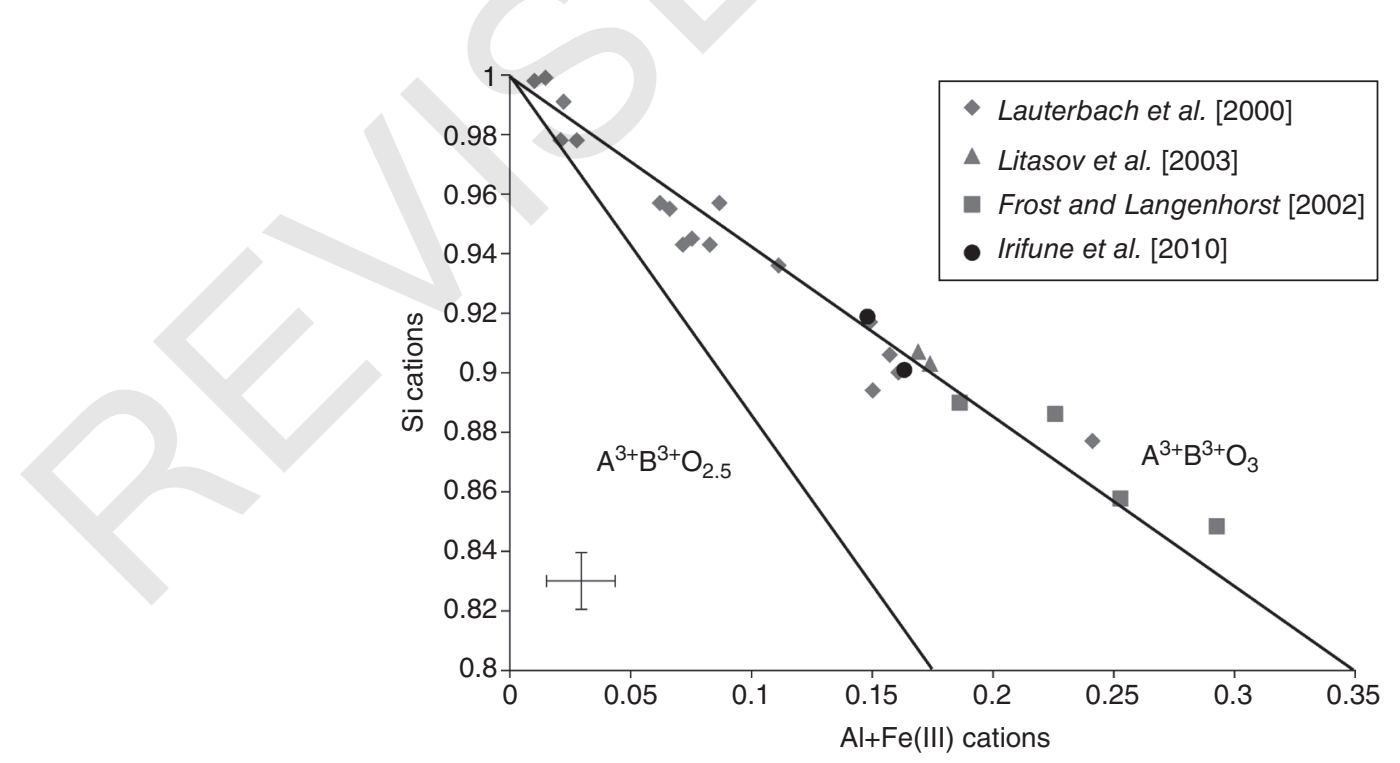

Figure 18.5 Trivalent cation substitution mechanisms in bridgmanite can be assessed through a plot of the proportion of $\mathrm{Si}$ cations in the structure, in atoms per 3 oxygen formula units, versus the combined trivalent cation content. The data points are from experiments that employed a range of bulk compositions and oxygen fugacities. 
the range of pyrolite samples, do not plot along the compositional curve expected if substitution occurs only through the $\mathrm{FeAlO}_{3}$ component. A proportion of trivalent cations seem to substitute onto the Si site with charge balance provided by the formation of an oxygen vacancy [Navrotsky, 1999]. This component appears to be also present in both 29 and $44 \mathrm{GPa}$ experiments of Irifune et al. [2010]. Although small, the removal of oxygen from the structure could greatly increase the compressibility of bridgmanite [Brodholt, 2000]. Defect perovskites are likely to be restricted to the upper parts of the lower mantle as a result of the large $\Delta V$ of the reaction

$$
4\left(\mathrm{Mg}_{3 / 4} \mathrm{Al}_{1 / 4}\right)\left(\mathrm{Si}_{3 / 4} \mathrm{Al}_{1 / 4}\right) \mathrm{O}_{3}+2 \mathrm{MgO}=2 \mathrm{MgAlO}_{2.5}+3 \mathrm{MgSiO}_{3} .
$$

As bridgmanite contains high levels of $\mathrm{Fe}^{3+}$ even in equilibrium with metallic iron, it is probably unavoidable that it contains significant $\mathrm{Fe}^{3+}$ in the lower mantle. Experiments suggest that lower mantle bridgmanite should have an $\mathrm{Fe}^{3+} / \sum \mathrm{Fe}$ of $\sim 0.6$, constraining the bulk lower mantle $\mathrm{Fe}^{3+} / \Sigma \mathrm{Fe}$ to be $\sim 0.4$. In contrast, estimates for the $\mathrm{Fe}^{3+} / \Sigma \mathrm{Fe}$ ratio of the upper mantle based on mantle xenoliths are <0.03 [Canil and O'Neill, 1996], although recent measurements on MORB glasses may imply slightly higher $\mathrm{Fe}^{3+} / \Sigma \mathrm{Fe}$ ratios [Cottrell and Kelley, 2011; 2013]. If the lower mantle is isochemical with the upper mantle, then the same bulk oxygen concentration can only be maintained if disproportionation of $\mathrm{FeO}$ occurs in the lower mantle, i.e.,

$$
3 \mathrm{FeO}_{(\text {bdg/fper })}=\mathrm{Fe}_{(\text {metal })}+\mathrm{Fe}_{2} \mathrm{O}_{3(\text { bdg })} .
$$

To maintain the bulk oxygen concentration would require the formation of approximately $1 \mathrm{wt} \%$ metallic iron. The metal would likely contain also Ni, C, S, and other siderophile elements. The very observation that bridgmanite with high $\mathrm{Fe}^{3+}$ contents coexists with metallic $\mathrm{Fe}$ demonstrates that the process must take place if bridgmanite forms under conditions of insufficient oxygen [Frost et al., 2004; Frost and McCammon, 2008]. As material upwells out of the bridgmanite stability field, $\mathrm{Fe}^{3+}$ will react with metallic iron to regain a similar $\mathrm{Fe}^{3+} / \mathrm{Fe}^{2+}$ ratio as the upper mantle. The opposite would occur for downwelling material. The bulk oxygen concentration of the entire mantle would remain a constant, as long as the metallic iron remained locked within the lower mantle assemblage, which is likely as it would be solid throughout much of the mantle. Even upon melting, dihedral angles between metallic liquid and lower mantle assemblages are high throughout most or all of the mantle, limiting connectivity at small metal melt fractions [Shi et al., 2013].

The upper mantle today is more oxidized than it would have been during core formation, when it was in equilibrium with core-forming metallic Fe. Currently the upper mantle is $\sim 5 \log$ units more oxidized than the stability of metallic iron, and measurements on some of the oldest rocks and minerals seem to imply that this oxidation process occurred during or very soon after core formation [Canil, 1997; Delano, 2001; Trail et al., 2011]. The mechanism by which the oxidation process occurred is important because it would have influenced the nature of volatile species degassing from the mantle. At iron metal saturation degassing species would have been dominated by $\mathrm{H}_{2}$ and $\mathrm{CH}_{4}$, whereas the more oxidized species $\mathrm{CO}_{2}$ and $\mathrm{H}_{2} \mathrm{O}$ were important for forming the early atmosphere and hydrosphere.

The formation of $\mathrm{Fe}^{3+}$-bearing bridgmanite in the lower mantle raises a possibility by which this oxidation could have occurred. As the lower mantle likely formed before the end of core formation, it would have formed from material initially poor in $\mathrm{Fe}^{3+}$. Iron metal should, therefore, have formed with bridgmanite. If, toward the end of core formation, some (approximately 10\%) of this metallic iron separated to the core, the remaining lower mantle material would contain proportionately more oxygen. Whole-mantle mixing of this oxygen-enriched material would raise the oxidation state of the mantle to the apparent present-day value. Figure 18.6 shows one plausible mechanism by which this could happen, i.e., disproportionated metal is removed from the mantle to the core by core-forming diapirs [Frost et al., 2004; Frost and McCammon, 2008].

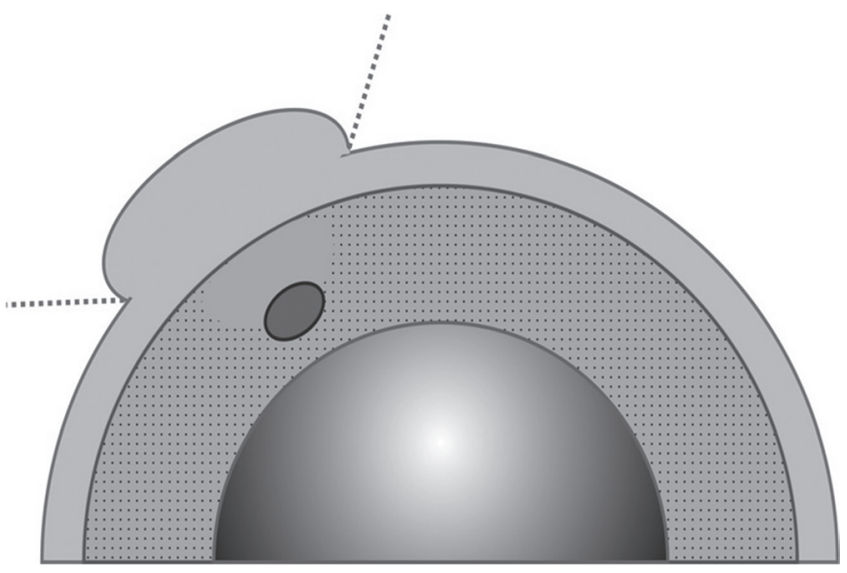

Figure 18.6 Cartoon showing one possible mechanism to oxidize the mantle during accretion and core formation. As the lower mantle forms, Fe metal and $\mathrm{Fe}^{3+}$-rich bridgmanite are produced by disproportionation of FeO. As the cores of accreting planetesimals pass through the lower mantle, some of this metal is entrained and separates to the core. This leaves the lower mantle enriched in oxygen, which after whole-mantle convection raises the oxygen fugacity of the upper mantle. Approximately $10 \%$ Fe metal would have to be lost to the core to explain the increase in the redox state of Earth's upper mantle compared to that expected during core formation. 
A further possibility would be that the entire lower mantle lost Fe metal to the core, which would have left it oxygen rich in comparison to the upper mantle. This would seem to require that the lower mantle has also remained isolated from the upper mantle because even small amounts of mixing would have continued to raise the upper mantle oxygen fugacity, which appears to have remained constant over geological time [Canil, 1997]. It has also been proposed, however, that carbon as diamond or graphite may reduce $\mathrm{Fe}^{3+}$ in ascending mantle as it oxidizes to form $\mathrm{CO}_{2}$ melt components through the reaction

$$
\mathrm{C}+2 \mathrm{Fe}_{2} \mathrm{O}_{3}=4 \mathrm{FeO}+\mathrm{CO}_{2},
$$

thus masking the $\mathrm{Fe}^{3+} / 2 \mathrm{Fe}$ ratio of the deeper mantle [O'Neill et al., 1993; Stagno et al., 2013]. One quite interesting observation is that OIB magmas are often estimated to have higher $\mathrm{CO}_{2}$ concentrations than MORB [e.g., Dixon et al., 1997; Aubaud et al., 2005]. Higher carbon concentrations in the OIB source would imply that the source at depth has a much higher $\mathrm{Fe}^{3+} / \Sigma \mathrm{Fe}$ ratio but that this is reduced as carbon oxidizes to $\mathrm{CO}_{2}$ during decompression. In this way carbon concentrations in the OIB source might mask a very large initial $\mathrm{Fe}^{3+} / \Sigma \mathrm{Fe}$ ratio in the lower mantle, which could remove the necessity for the lower mantle to contain metallic iron.

\subsection{CONCLUSIONS}

Here we have attempted to summarize the arguments for and against large-scale chemical differentiation of the mantle and to examine the variations in mineral chemistry that need to be accounted for when placing constraints on the compositional and thermal structure of the lower mantle using seismic velocity observations. Given the still challenging experimental conditions encompassed by the lower mantle, significant uncertainties remain in experimentally determined phase equilibria and elasticity data. Although a number of mechanisms that may be important in the lower mantle have been recognized, consistent models for the operation of these influences have yet to be developed. In particular, defect structures and spin transitions are rarely considered in thermodynamic models but may have important effects on major element partitioning between phases and on seismic velocities. Disproportionation of ferrous iron may also have a major effect by changing the elastic properties of bridgmanite and by affecting iron partitioning with ferropericlase. It should be possible to employ a self-consistent thermodynamic approach that combines experimental data on both phase equilibria, i.e., chemical partitioning, and equation-of-state measurements into a single model for lower mantle properties. The development of such models will ensure consistency between elasticity models and phase equilibrium studies and provide an independent technique by which to assess the composition of Earth's deep interior.

\section{ACKNOWLEDGMENTS}

An earlier version of this manuscript was improved thanks to the comments of two anonymous reviewers. This work was funded through the support of European Research Council (ERC) Advanced Grant “DEEP”(227893).

\section{REFERENCES}

Agee, C. B., and D. Walker (1988), Mass balance and phase density constraints on early differentiation of chondritic mantle, Earth Planet. Sci. Lett., 90, 144-156.

Albarède, F., and R. D. van der Hilst (2002), Zoned mantle convection, Philos. Trans. R. Soc. Lond., 360, 2569-2592.

Allegre, C. J., J. P. Poirier, E. Humbler, and A. W. Hofmann (1995), The chemical composition of the Earth, Earth Planet Sci. Lett., 134, 515-526.

Anderson, D. L. (1968), Chemical inhomogeneity of the mantle, Earth Planet. Sci. Lett., 5, 89-94.

Anderson, D. L. (1979), Chemical stratification of the mantle, J. Geophys. Res., 84, 6297-6298.

Andrault, D., N. Bolfan-Casanova, G. Lo Nigro, M. A. Bouhifd, G. Garbarino, and M. Mezouar (2011), Solidus and liquidus profiles of chondritic mantle: Implication for melting of the Earth across its history, Earth Planet. Sci. Lett., 304, 251-259.

Andrault, D., S. Petitgirard, G. Lo Nigro, J. L. Devidal, G. Veronesi, G. Garbarino, and M. Mezouar (2012), Solid-liquid iron partitioning in Earth's deep mantle, Nature, 487, 354-357.

Antonangeli, D., J. Siebert, J. Badro, D. L. Farber, G. Fiquet, G. Morard, and F. J. Ryerson (2010), Composition of the Earth's inner core from high-pressure sound velocity measurements in Fe-Ni-Si alloys, Earth Planet. Sci. Lett., 295, 292-296.

Arevalo, R., W. F. McDonough, and M. Luong (2009), The $\mathrm{K} / \mathrm{U}$ ratio of the silicate Earth: Insights into mantle composition, structure and thermal evolution, Earth Planet. Sci. Lett., 278: 361-369.

Aubaud, C., P. Francoise, R. Hekinian, and M. Javoy (2005), Degassing of $\mathrm{CO}_{2}$ and $\mathrm{H}_{2} \mathrm{O}$ in submarine lavas from the Society hotspot, Earth Planet. Sci. Lett. 235, 511-527.

Austermann, J., B. T. Kaye, J. X. Mitrovica, and P. Huybers (2014) A statistical analysis of the correlation between large igneous provinces and lower mantle seismic structure, Geophys. J. Int. 197, 1-9.

Auzende, A. L., J. Badro, F. J. Ryerson, P. K. Weber, S. J. Fallon, A. Addad, J. Siebert, and G. Fiquet (2008), Element partitioning between magnesium silicate perovskite and ferropericlase: New insights into bulk lower-mantle geochemistry, Earth. Planet. Sci. Lett., 269, 164-174.

Badro, J. (2014), Spin transitions in mantle minerals., Аnnu. Rev. Earth Planet. Sci., 42, 231-248.

Badro, J., G. Fiquet, F. Guyot, J. P. Rueff, V. V. Struzhkin, and G. Vankó (2003), Iron partitioning in Earth's mantle: Toward a deep lower mantle discontinuity, Science, 300, 789-791. 
Badro J., A. S. Cote, and J. P. Brodholt (2014), A seismologically consistent compositional model of Earth's core, PNAS, 132, $7542-7545$.

Ballhaus, C., R. F. Berry, and D. H. Green (1991), High pressure experimental calibration of the olivine-orthopyroxene-spinel oxygen geobarometer: Implications for the oxidation state of the upper mantle., Contrib. Mineral. Petrol., 107, 27-40.

Bina C. R., and G. Helffrich (2014), Geophysical constraints upon mantle composition, in Treatise on Geochemistry, vol. 2, 2nd ed., edited by H. D. Holland and K. K. Turekian, pp. 41-65,Elsevier, Oxford, doi:10.1016/B978-0-08-095975-7.00202-3.

Birch, F. (1952). Elasticity and constitution of the earth's interior, J. Geophys. Res., 57, 227-286.

Boffa Ballaran, T., A. Kurnosov, K. Glazyrin, D. J. Frost, M. Merlini, M. Hanfland, and R. Caracas (2012), Effect of chemistry on the compressibility of silicate perovskite in the lower mantle, Earth Planet. Sci. Lett., 333-334, 181-190.

Brodholt, J. P. (2000), Pressure-induced changes in the compression mechanism of aluminous perovskite in the Earth's mantle, Nature, 407, 620-622.

Burns, R. G. (1993), Mineralogical Application of Crystal Field Theory, Cambridge Univ. Press, Cambridge.

Campbell, I. H., and HStC O'Neill (2012), Evidence against a chondritic Earth, Nature, 483, 553-558.

Canil, D. (1997), Vanadium partitioning and the oxidation state of Archean komatiite magmas, Nature, 389, 842-845.

Canil, D., and HStC O’Neill (1996), Distribution of ferric iron in some upper-mantle assemblages,. J. Petrol., 37, 609-635.

Canup, R. M. (2004), Simulations of a late lunar-forming impact, Icarus, 168, 433-456.

Carlson, R. W., E. Garnero, T. M. Harrison, J. Li., M. Manga, W. F. McDonough, S. Mukhopadhyay, B. Romanowicz, D. Rubie, Zhong S., and Williams Q. (2014), How did early Earth become our modern world? Annu. Rev. Earth Planet. Scie., 42, 151-178.

Catalli, K., S.-H Shim, V. B. Prakapenka, J. Zhao, W. Struhahn, P. Chow, Y. Xiao, H. Liu, H. Cynn, and W. J. Evans (2010), Spin state of ferric iron in $\mathrm{MgSiO}_{3}$ perovskite and its effect on elastic properties, Earth Planet. Sci. Lett., 289, 68-75.

Catalli, K., S. H. Shim, P. Dera, V. B. Prakapenka, J. Zhao, W. Sturhahn, P. Chow, Y. Xiao, H. Cynn, and W. J. Evans (2011), Effects of the $\mathrm{Fe}^{3+}$ spin transition on the properties of aluminous perovskite-New insights for lowermantle seismic heterogeneities., Earth Planet. Sci. Lett., 310, 293-302.

Chantel, J., D. J. Frost, C. A. McCammon, Z. C. Jing, and Y. B. Wang (2012), Acoustic velocities of pure and iron-bearing magnesium silicate perovskite measured to $25 \mathrm{GPa}$ and $1200 \mathrm{~K}$, Geophys. Res. Lett., 39, L19,307, doi:10.1029/2012GL053075.

Christensen, U. R., and D. A. Yuen (1985), Layered convection induced by phase-transitions, J. Geophys. Res. 90, 291-300.

Condie, K. C. (1998), Episodic continental growth and supercontinents: A mantle avalanche connection? Earth Planet. Sci. Lett., 163, 97-108.

Corgne, A., C. Liebske, B. J. Wood, D. C. Rubie, and D. J. Frost (2005), Silicate perovskite-melt partitioning of trace elements and geochemical signature of a deep perovskitic reservoir, Geochim. Cosmochim. Acta, 69 (2), 485-496.
Cottaar, S., T. Heister, I. Rose, and C. Unterborn (2014), BurnMan: A lower mantle mineral physics toolkit, Geochem. Geophys. Geosyst, 15, 1164-1179.

Cottrell, E., and K. A. Kelley (2011), The oxidation state of Fe in MORB glasses and the oxygen fugacity of the upper mantle, Earth Planet. Sci. Lett., 305, 270-282.

Cottrell E., and K. A. Kelley (2013), Redox heterogeneity in midocean ridge basalts as a function of mantle source, Science, 340, 1314-1317.

Creager, K. C., and T. H. Jordan (1984), Slab penetration into the lower mantle, J. Geophys. Res. 89, 3031-3049.

Dauphas, N., F. Poitrasson, C. Burkhardt, H. Kobayashi, K. Kurosawa (2015), Planetary and meteoritic $\mathrm{Mg} / \mathrm{Si}$ and image variations inherited from solar nebula chemistry, Earth Planet. Sci. Lett., 427, 236-248.

Delano, J. W. (2001), Redox history of the Earth's interior since approximately $3900 \mathrm{Ma}$ : Implications for prebiotic molecules. Orig. Life Evol. Biospheres J. Int. Soc. Study Orig. Life, $31,311-41$.

Dixon, J. E., D. A. Clague, P. Wallace, and R. Poreda (1997), Volatiles in alkalic basalts from the north arch volcanic field, Hawaii: Extensive degassing of deep submarine-erupted alkalic series lavas, J. Petrol., 38, 911-939.

Dziewonski, A. M., and L. Anderson (1981), Preliminary reference Earth model, Phys. Earth Planet. Inter., 25, 297-356.

Frost, D. J., F. Langenhorst (2002), The effect of $\mathrm{Al}_{2} \mathrm{O}_{3}$ on Fe$\mathrm{Mg}$ partitioning between magnesiowüstite and magnesium silicate perovskite, Earth Planet. Sci. Lett., 199, 227-241.

Frost, D. J., and C. A. McCammon (2008), The redox state of Earth's mantle, Annu. Rev. Earth Planet. Sci. 36, 389-420.

Frost, D. J., C. Liebske, F. Langenhorst, C. A. McCammon, R. G. Tronnes, and D. C. Rubie (2004), Experimental evidence for the existence of iron-rich metal in the Earth's lower mantle, Nature, 428, 409-412.

Fujino, K., D. Nishio-Hamane, Y. Seto, N. Sata, T. Nagai, T. Shinmei, T. Irifune, H. Ishii, N. Hiraoka, Y. Q. Cai, and K.-D. Tsuei (2012), Spin transition of ferric iron in Albearing $\mathrm{Mg}$-perovskite up to $200 \mathrm{GPa}$ and its implication for the lower mantle, Earth Planet. Sci. Lett. 317-318, 407-412.

Fukao, Y., and O. Masayuki (2013), Subducted slabs stagnant above, penetrating through, and trapped below the $660 \mathrm{~km}$ discontinuity, J. Geophys. Res., 118, 5920-5938.

Fukao, Y., S., Widiyantoro and M. Obayashi, (2001), Stagnant slabs in the upper and lower mantle transition region, Rev. Geophy., 39, 291-323.

Gaherty, J. B., and B. H. Hager (1994) Compositional vs. thermal buoyancy and the evolution of subducted lithosphere, Geophys. Res. Lett., 21, 141-144.

Glazyrin, K., T. Boffa Ballaran, D. J. Frost, C. McCammon, A. Kantora, M. Merlinie, M. Hanfland, and L. Dubrovinsky (2014), Magnesium silicate perovskite and effect of iron oxidation state on its bulk sound velocity at the conditions of the lower mantle, Earth Planet. Sci. Lett., 393, 182-186.

Grand, S. P. (2002), Mantle shear-wave tomography and the fate of subducted slabs, Philos. Trans. R. Soc. Lond. Seri. A Math. Phys. Eng. Sci. 360, 2475-2491. 
Grocholski, B., S.-H Shim, W. Sturhahn, J. Zhao, Y. Xiao, and P. C. Chow (2009), Spin and valence states of iron in $\left(\mathrm{Mg}_{0.8} \mathrm{Fe}_{0.2}\right) \mathrm{SiO}_{3}$, Geophys. Res. Lett. 36, L24,303.

Hofmann, A. W. (2014), Sampling mantle heterogeneity through oceanic basalts: Isotopes and trace elements, in Treatise on Geochemistry, 2nd ed., vol. 2, edited by H. D. Holland and K. K. Turekian) pp. 67-101, Elsevier, Oxford, doi:10.1016/ B978-0-08-095975-7.00202-3.

Hsu, H., P. Blaha, M. Cococcioni, and R. M. Wentzcovitch (2011), Spin crossover and hyperfine interactions of ferric iron in $\mathrm{MgSiO}_{3}$ perovskite, Phys. Rev. Lett. 106, 118,501.

Hsu, H., Y. G., Yu and R. M. Wentzcovitch, (2012) Spin crossover of iron in aluminous $\mathrm{MgSiO}_{3}$ perovskite and postperovskite, Earth Planet. Sci. Lett., 359-360, 34-39.

Hummer, D. R., and Y. Fei (2012), Synthesis and crystal chemistry of $\mathrm{Fe}^{3+}$-bearing $\left(\mathrm{Mg}, \mathrm{Fe}^{3+}\right)\left(\mathrm{Si}_{1} \mathrm{Fe}^{3+}\right) \mathrm{O}_{3}$ perovskite, Am. Mineral., 97, 1915-1921.

Irifune T. (1994), Absence of an aluminous phase in the upper part of the Earth's lower mantle, Nature, 370, 131-133.

Irifune, T. and T. Tsuchiya, (2007), Mineralogy of the Earth: Phase transitions and mineralogy of the lower mantle, in Treatise on Geophysics, vol. 2 edited by G. Schubert, pp. 33-62, Elsevier, Amsterdam, The Netherlands.

Irifune T., T. Shinmei, C. A. McCammon, N. Miyajima, D. C. Rubie, and D. J. Frost (2010), Iron partitioning and density changes of pyrolite in Earth's lower mantle, Science 327, 193-195.

Ito, E., and E. Takahashi (1989), Post-spinel transformations in the system $\mathrm{Mg}_{2} \mathrm{SiO}-\mathrm{Fe}_{2} \mathrm{SiO}_{4}$ and some geophysical implications, J. Geophys. Res., 94, 10,637-10,646.

Ito, E., M. Akaogi, L. Topor, and A. Navrotsky (1990), Negative pressure-temperature slopes for reactions forming $\mathrm{MgSiO}_{3}$ from calorimetry, Science, 249, 1275-1278.

Ito, E., T. Katsura, A. Kubo, and M. Walter (2004), Melting experiments of mantle materials under lower mantle conditions with implication to fractionation in magma ocean, Phys. Earth Planet. Inter., 143-144, 397-406.

Jackson, C. R. M., L. B. Ziegler, H. L. Zhang, M. G. Jackson, and D. R. Stegman (2014), A geochemical evaluation of potential magma ocean dynamics using a parameterized model for perovskite crystallization, Earth. Planet. Sci. Lett., 392, 154-165.

Jackson, I. (1983) Some geophysical constraints on the chemical composition of the Earth's lower mantle, Earth. Planet. Sci. Lett. 62,91-103.

Jackson, M. G., and A. M. Jellinek (2013), Major and trace element composition of the high $\mathrm{He}-3 / \mathrm{He}-4$ mantle: Implications for the composition of a nonchondritic Earth, Geochem. Geophys. Geosyst., 14, 2954-2976.

Jacobsen S. B., and G. J. Wasserburg (1979), The mean age of mantle and crustal reservoirs. J. Geophys. Res., 84, 7411-7427.

Jochum K. P., A. W. Hofmann, E. Ito, H. M. Seufert, and W. M. White (1983), K, U and Th in mid-ocean ridge basalt glasses and heat-production, $\mathrm{K} / \mathrm{U}$ and $\mathrm{K} / \mathrm{Rb}$ in the mantle, Nature, 306, 431-436.

Kaminsky, F. (2012),. Mineralogy of the lower mantle: A review of "super-deep" mineral inclusions in diamond, Earth-Sci. Rev., 110, 127-147.
Kato, T., A. E. Ringwood, and T. Irifune (1988), Experimental determination of element partitioning between silicate perovskites, garnets and liquids: Constraints on early differentiation of the mantle, Earth Planet. Sci. Lett., 89, 123-145.

Katsura, T., and E. Ito (1996), Determination of Fe-Mg partitioning between perovskite and magnesiowüstite, Geophys. Res. Lett., 23, 2005-2008.

Katsura, T., H. Yamada, T. Shinmei, A. Kubo, S. Ono, M. Kanzaki, A. Yoneda, M. J. Walter, S. Urakawa, E. Ito, K. Funakoshi, and W Utsumi (2003), Post-spinel transition in $\mathrm{Mg}_{2} \mathrm{SiO}_{4}$ determined by in situ X-ray diffractometry, Phys. Earth Planet. Inter. 136, 11-24.

Kind, R., and X. Li (2007), Deep Earth structure-Transition zone and mantle discontinuities, in edited by G. Schubert, B. Romanowicz, A. Dziewonski, Treatise on Geophy, Vol. 1, Seismology and the Structure of the Earth, pp. 591-612. Elsevier, Amsterdam.

Kobayashi, Y., T. Kondo, E. Ohtani, N. Hirao, N. Miyajima, T. Yagi, T. Nagase, and T. Kikegawa (2005), Fe-Mg partitioning between $(\mathrm{Mg}, \mathrm{Fe}) \mathrm{SiO}_{3}$ post-perovskite, perovskite, and magnesiowustite in the Earth's lower mantle, Geophys. Res. Lett., 32, L19,301, doi: 10.1029/2005GL023257.

Labrosse, S., J. W. Hernlund, and N. Coltice (2007), A crystallizing dense magma ocean at the base of the Earth's mantle, Nature, 450, 866-869.

Larimer, J. W., and E. Anders (1970), Chemical fractionations in meteorites-III. Major element fractionations in chondrites, Geochim. Cosmochim. Acta, 34, 367-387.

Lassiter, J. C., and E. H. Hauri (1998), Osmium-isotope variations in Hawaiian lavas: Evidence for recycled oceanic lithosphere in the Hawaiian plume, Earth Planet. Sci. Lett., 164, 483-496.

Lauterbach, S., C. A. McCammon, P. van Aken, F. Langenhorst, and F. Seifert (2000), Mossbauer and ELNES spectroscopy of $(\mathrm{Mg}, \mathrm{Fe})(\mathrm{Si}, \mathrm{Al}) \mathrm{O}_{3}$ perovskite: A highly oxidised component of the lower mantle, Contrib. Mineral. Petrol., 138, 17-26.

Li, C., and R. D. van der Hilst (2010), Structure of the upper mantle and transition zone beneath Southeast Asia from traveltime tomography, J. Geophys. Res., 115, B07308, doi:10.1029/2009JB006882.

Li, X-D, and B. Romanowicz (1996), Global mantle shear velocity model developed using nonlinear asymptotic coupling theory, J. Geophys. Res., 101, 22,245-22,272.

Liebske, C., and D. J. Frost (2012), Melting phase relations in the $\mathrm{MgO}-\mathrm{MgSiO}_{3}$ system between 16 and $26 \mathrm{GPa}$ : Implications for melting in Earth's deep interior, Earth Planet. Sci. Lett., 345, 159-170.

Liebske, C., A. Corgne, D. J. Frost, D. C. Rubie, and B. J. Wood (2005), Compositional effects on element partitioning between $\mathrm{Mg}$-silicate perovskite and silicate melts, Contrib. Mineral. Petrol., 149, 113-128.

Lin, J.-F., S. Speziale, Z. Mao, and H. Marquardt (2013), Effects of the electronic spin transitions of iron in lower mantle minerals: Implications for deep mantle geophysics and geochemistry, Rev. Geophys., 51, 244-275, doi:10.1002/rog.20010.

Litasov, K., E. Ohtani, F. Langenhorst, H. Yurimoto, T. Kubo, and T. Kondo (2003), Water solubility in Mg-perovskites, and water storage capacity in the lower mantle, Earth. Planet. Sci. Lett., 211, 189-203. 
Liu, L. G. (1974), Silicate perovskite from phase transformations of pyrope-garnet at high pressure and temperature, Geophys. Res. Lett., 1, 277-280.

Liu, L. G. (1975) Post-oxide phases of forsterite and enstatite, Geophys. Res. Lett., 2, 417-419.

Liu, L. G. (1976), The post-spinel phases of forsterite, Nature, $262,770-772$.

McCammon, C. (1997), Perovskite as a possible sink for ferric iron in the lower mantle, Nature, 387, 694-696.

McCammon C. A., S. Lauterbach, F. Seifert, F. Langenhorst, and P. A. van Aken (2004) Iron oxidation state in lower mantle mineral assemblages - I. Empirical relations derived from highpressure experiments. Earth Planet. Sci. Lett. 222, 435-449.

McDonough, W. F., and S.-S. Sun (1995), The composition of the Earth, Chem. Geol., 120, 223-253.

Murakami, M., K. Hirose, K. Kawamura, N. Sata, and Y. Ohishi (2004), Post-perovskite phase transition in $\mathrm{MgSiO}_{3}$, Science, 304(5672), 855-858.

Murakami, M., Y. Ohishi, N. Hirao, K. Hirose (2012), A perovskitic lower mantle inferred from high-pressure, high-temperature sound velocity data, Nature 485, 90-94.

Myhill, R. (2013), Slab buckling and its effect on the distributions and focal mechanisms of deep-focus earthquakes. Geophys J. Int., 192, 837-853.

Nakajima, Y., D. J., Frost, D. C. Rubie (2012), Ferrous iron partitioning between magnesium silicate perovskite and ferropericlase and the composition of perovskite in the Earth's lower mantle, J. Geophys. Res. 117, B08,201, doi: 10.1029/ 2012JB009151.

Navrotsky, A (1999), A lesson from ceramics, Science, 284, $1788-1789$.

Ni, S., E. Tan, M. Gurnis, and D. Helmberger (2002), Sharp sides to the African superplume, Science, 296, 1850-1852.

Nishiyama N., and T. Yagi (2003), Phase relation and mineral chemistry in pyrolite to 2200 degrees $\mathrm{C}$ under the lower mantle pressures and implications for dynamics of mantle plumes, J. Geophys. Res., 108, 2255 doi:10.1029/2002JB002216.

Nomura, R., H. Ozawa, S. Tateno, K. Hirose, J. Hernlund, S. Muto, H. Ishii, and N. Hiraoka (2011), Spin crossover and ironrich silicate melt in the Earth's deep mantle, Nature, 473, 199-202.

Oliver, J. and B. Isacks (1967), Deep earthquake zones, anomalous structures in upper mantle and lithosphere, J. Geophys. Res. 72, 4259-4275.

O'Neill, H.St.C, and H. Palme (1998), Composition of the silicate earth: Implications for accretion and core formation, in The Earth's Mante-Composition, Structure and Evolution, edited by I. Jackson, pp. 3-126, Cambridge Univ. Press, Cambridge.

O'Neill, HStC, D. C. Rubie, D. Canil, C. A. Geiger, and C. R. Ross (1993), Ferric iron in the upper mantle and in transition zone assemblages: Implications for relative oxygen fugacities in the mantle, in Evolution of the Earth and Planets, Geophys. Monogr. 74, edited by E. Takahashi, R. Jeanloz, and D. C. Rubie, pp. 73-88, AGU, Washington, D.C.

Poirier, J. P. (1994), Light elements in the Earth's outer core-A critical review, Phys. Earth Planet. Inter., 85, 319-337.

Richter, F., and D. McKenzie (1978), Simple plate models of mantle convection, J. Geophys., 44, 441-471.
Richter, F. M., and C. E. Johnson (1974), The stability of a chemically layered mantle, J. Geophys. Res., 79, 1635-1639.

Ringwood, A. E. (1975), Composition and Petrology of the Earth's Mantle, McGraw-Hill, New York.

Ringwood, A. E. (1982), Phase transformations and differentiation in subducted lithosphere: Implications for mantle dynamics, basalt petrogenesis, and crustal evolution, J. Geol. 90, 611-643.

Ringwood, A. E. (1991), Phase transformations and their bearing on the constitution and dynamics of the mantle, Geochim. Cosmochim. Acta, 55, 2083-2110.

Saikia, A., D. J. Frost, and D. C. Rubie (2008), Splitting of the 520- kilometer seismic discontinuity and chemical heterogeneity in the mantle, Science, 319, 1515-1518.

Sakai, T., E. Ohtani, H. Terasaki, N. Sawada, Y. Kobayashi, M. Miyahara, M. Nishijima, N. Hirao, Y. Ohishi, T. Kikegawa (2009), Fe-Mg partitioning between perovskite and ferropericlase in the lower mantle, Am. Mineral., 94, 921-925.

Shi, C. Y., L. Zhang, W. Yang, Y. Liu, J. Wang, Y. Meng, J. C. Andrews, and WL Mao (2013), Formation of an interconnected network of iron melt at Earth's lower mantle conditions, Nature Geosci., 6, 971-975.

Sinmyo, R., and K. Hirose (2013), Iron partitioning in pyrolitic lower mantle, Phys. Chem. Minerals, 40, 107-113.

Sinmyo, R., K. Hirose, D. Nishio-Hamane, Y. Seto, K. Fujino, N. Sata, and Y. Ohishi (2008), Partitioning of iron between perovskite/postperovskite and ferropericlase in the lower mantle, J. Geophys. Res. 113, B11,204, doi: 10.1029/ 2008JB005730.

Sobolev, A. V., A. W. Hofmann, and I. K. Nikogosian (2000), Recycled oceanic crust observed in "ghost plagioclase" within the source of Mauna Loa lavas, Nature, 404, 986-990, doi:10.1038/35010098.

Solheim, L. P., and W. R. Peltier (1994), Avalanche effects in phase transition modulated thermal convection: A model of Earth's mantle, J. Geophys. Res. 99, 6997-7018.

Solomatov, V. S., and C. C. Reese (2008), Grain size variations in the Earth's mantle and the evolution of primordial chemical heterogeneities, J. Geophys. Res., 113, 10.1029/2007JB005319.

Speziale, S., V. E. Lee, S. M. Clark, J. F. Lin, M. P. Pasternak, and R. Jeanloz (2007). Effects of Fe spin transition on the elasticity of $(\mathrm{Mg}, \mathrm{Fe}) \mathrm{O}$ magnesiowüstites and implications for the seismological properties of the Earth's lower mantle, J. Geophys. Res, 112, B10212, doi:10.1029/2006JB004730.

Stagno, V., O. Dickson, C. A. McCammon, and D. J. Frost (2013), The oxidation state of the mantle and the extraction of carbon from Earth's interior, Nature, 493, 84-88. doi:10.1038/nature11679.

Stixrude, L., and R. Jeanloz (2007), Constraints on seismic models from other disciplines - Constraints from mineral physics on seismological models, in Treatise on Geophysic, vol. 1: Seismology and the Structure of the Earth, edited by G. Schubert, pp. 775-803, Elsevier., Oxford, doi:10.1016/ B978-044452748-6/00026-2.

Su, W.-J., R. L. Woodward, and A. M. Dziewonski (1994), Degree 12 model of shear velocity heterogeneity in the mantle, J. Geophys. Res. Solid Earth, 99, 6945-6980.

Tackley, P. J., D. J. Stevenson, G. A. Glatzmaier, and G. Schubert (1993), Effects of an endothermic phase transition at $670 \mathrm{~km}$ 
depth in a spherical model of convection in the Earth's mantle, Nature, 361, 699-704.

Tange, Y., E. Takahashi, Y. Nishihara, and K. I. Funakoshi, N. Sata (2009), Phase relations in the system $\mathrm{MgO}-\mathrm{FeO}-\mathrm{SiO}_{2}$ to $50 \mathrm{GPa}$ and 2000 degrees C: An application of experimental techniques using multianvil apparatus with sintered diamond anvils, J. Geophys. Res. 114,B02,214, doi:10.1029/2008JB005891.

Torsvik, T. H., M. A. Smethurst, K. Burke, and B. Steinberger (2008), Long term stability in Deep Mantle structure: Evidence from the ca. 300 Ma Skagerrak-Centered Large Igneous Province (the SCLIP), Earth Planet. Sci. Lett., 267, $444-452$.

Trail, D., E. B. Watson, and N. D. Tailby (2011), The oxidation state of Hadean magmas and implications for early Earth's atmosphere, Nature, 480, 79-82.

Tschauner, O., C. Ma, J. R. Beckett, C. Prescher, V. B. Prakapenka, and G. R. Rossman (2014), Discovery of bridgmanite, the most abundant mineral in Earth, in a shocked meteorite, Science, 346, 1100-1102, doi:10.1126/science.1259369.

van der Hilst, R. D., S. Widiyantoro, and E. R. Engdahl (1997), Evidence for deep mantle circulation from global tomography, Nature, 386, 578-584.

Walter, M. (2003), Melt extraction and compositional variability in mantle lithosphere, in The Mantle and Core, (R. W. Carlson), vol. 2, Treatise on Geochemistry, edited by H. D. Holland and K. K. Turekian, pp. 363-394, Elsevier-Pergamon, Oxford.
Walter, M. J., E. Nakamura, R. G. Tronnes, and D. J. Frost (2004), Experimental constraints on crystallization differentiation in a deep magma ocean, Geochim. Cosmochim. Acta, 68, 4267-4284.

Wang, X., T. Tsuchiya, and A. Hase (2015), Computational support for a pyrolitic lower mantle containing ferric iron, Nature Geosci. 8, 556-559, doi:10.1038/ngeo2458.

Wasson, J. T. and G. W. Kallemeyn (1988), Composition of chondrites, Philos. Trans. R. Soc. Lond. A, 325, 535-544.

Wood, B. J., and D. C. Rubie (1996), The effect of alumina on phase transformations at the $660-\mathrm{km}$ discontinuity from $\mathrm{Fe}-\mathrm{Mg}$ partitioning experiments, Science, 273, $1522-1524$.

Workman, R. K., S. R. Hart (2005), Major and trace element composition of the depleted MORB mantle (DMM), Earth Planet. Sci. Lett., 231, 53-72.

Xu, W., C. Lithgow-Bertelloni, L. Stixrude, and J. Ritsema (2008), The effect of bulk composition and temperature on mantle seismic structure, Earth Planet. Sci. Lett., 275, 70, doi:10.1016/ j.epsl.2008.08.012.

Zhang, L., Y. Meng, W. Yang, L. Wang, W. L. Mao, Q.-S. Zeng, J. S. Jeong, A. J. Wagner, K. A. Mkhoyan, W. Liu, R. $\mathrm{Xu}$, and H. K. Mao (2014), Disproportionation of (Mg,Fe) $\mathrm{SiO}_{3}$ perovskite in Earth's deep lower mantle, Science, 344, 877-882. 